NBER WORKING PAPER SERIES

\title{
WHAT ARE FIRMS? EVOLUTION FROM BIRTH TO PUBLIC COMPANIES
}

\author{
Steven N. Kaplan \\ Berk A. Sensoy \\ Per Strömberg \\ Working Paper 11581 \\ http://www.nber.org/papers/w11581
NATIONAL BUREAU OF ECONOMIC RESEARCH
1050 Massachusetts Avenue
Cambridge, MA 02138
August 2005

Kaplan: University of Chicago Graduate School of Business and NBER, Sensoy: University of Chicago Graduate School of Business, and Strömberg: SIFR. This research has been supported by the Kauffman Foundation, by the Lynde and Harry Bradley Foundation and the Olin Foundation through grants to the Center for the Study of the Economy and the State, and by the Center for Research in Security Prices. We thank the venture capital partnerships for providing data. We thank Andres Almazan, Ulf Axelson, George Baker, Ola Bengtsson, Effi Benmelech, Patrick Bolton, Zsuzsanna Fluck, Oliver Hart, Thomas Hellman, Bengt Holmstrom, Josh Lerner, Jeremy Stein, Krishnamurthy Subramanian, Lucy White, Luigi Zingales, and seminar participants at the CEPR Summer Symposium at Gerzensee, Federal Reserve Bank of New York, Harvard University, NBER Entrepreneurship Group, Stockholm School of Economics, and the University of Chicago for helpful comments. Address correspondence to Steven Kaplan, University of Chicago Graduate School of Business, 5807 South Woodlawn Avenue, Chicago, IL 60637 or e-mail at skaplan@uhicago.edu.The views expressed herein are those of the author(s) and do not necessarily reflect the views of the National Bureau of Economic Research.

(C2005 by Steven N. Kaplan, Berk A. Sensoy and Per Strömberg. All rights reserved. Short sections of text, not to exceed two paragraphs, may be quoted without explicit permission provided that full credit, including (C) notice, is given to the source. 
What Are Firms? Evolution from Birth to Public Companies

Steven N. Kaplan, Berk A. Sensoy and Per Strömberg

NBER Working Paper No. 11581

August 2005

JEL No. L2, G3

\section{$\underline{\text { ABSTRACT }}$}

We study how firm characteristics evolve from early business plan to initial public offering to public company for 49 venture capital financed companies. The average time elapsed is almost 6 years. We describe the financial performance, business idea, point(s) of differentiation, non-human capital assets, growth strategy, customers, competitors, alliances, top management, ownership structure, and the board of directors. Our analysis focuses on the nature and stability of those firm attributes. Firm business lines remain remarkably stable from business plan through public company. Within those business lines, non-human capital aspects of the businesses appear more stable than human capital aspects. In the cross-section, firms with more alienable assets have substantially more human capital turnover.

Steven Kaplan

Graduate School of Business

The University of Chicago

5807 South Woodlawn Avenue

Chicago, IL 60637

and NBER

skaplan@gsb.uchicago.edu

Berk Sensoy

Graduate School of Business

The University of Chicago

5807 South Woodlawn Avenue

Chicago, IL 60637

bsensoy@gsb.uchicago.edu
Per Stromberg

Swedish Institute for Financial Research

Saltmätargatan 19A

SE-113 59 Stockholm

SWEDEN

and NBER

per.stromberg@cifr.org 


\section{Introduction}

Since Coase (1937), economists have attempted to understand why firms exist and what constitutes firms. ${ }^{1}$ Despite the long history of theory and empirical work, there is little systematic or non-case evidence concerning what constitutes a firm at birth and how a firm evolves from birth to mature company. In this paper, we provide such evidence by studying 49 venture capital-financed firms from early business plan to initial public offering (IPO) to public company (three years after the IPO).

This exercise has two goals. First, we provide a systematic description of the early life and evolution of an important sample of firms. Second, we consider how our findings can be interpreted in relation to existing theories of the firm and what new theories might try to explain.

Our analysis begins with the identification and classification of firm characteristics when the firms are very young (at the time of an early business plan). Fewer than half the sample firms have revenues at that time. For each sample firm, we describe the financial performance, business idea, point(s) of differentiation, non-human capital assets and technology, growth strategy, customers, competitors, alliances, top management, ownership structure, and board of directors. We then consider how firm financial measures and firm characteristics evolve by describing the firms at the IPO and at the third annual report after the IPO. We pay particular attention to measuring if those characteristics remain constant, change, or disappear.

After describing the initial characteristics and evolution of these firms, we examine two crosssectional relationships. We consider the relation between human capital turnover and the nature of firm assets. Then, we consider the division of value between human and non-human capital assets by estimating the determinants of founder ownership.

In describing the initial characteristics of firms and how they evolve, we try to shed light on different theories of the firm. While some of these theories are motivated by specific examples or cases, we provide some of the first systematic and (relatively) large sample evidence on these issues.

Several theories emphasize the difference between non-human and human assets. For example, the basic assumption of the Hart-Moore framework is that firms are defined by their non-human assets. In the

\footnotetext{
${ }^{1}$ Both Holmstrom and Roberts (1998) and Gibbons (2004) describe and summarize some of this work.
} 
words of Hart (1995), “a firm’s non-human assets, then, simply represent the glue that keeps the firm together, whatever this may be ... Control over non-human assets leads to control over human assets... If non-human assets do not exist, then it is not clear what keeps the firm together.” (p. 57). Holmström (1999) comes to a similar conclusion, but argues that firm ownership of non-human assets allows the firm to structure internal incentives and to influence external parties (e.g., suppliers) who contract with the firm.

Two aspects of our analysis address these theories. First, we try to identify the "glue" that holds firms together and determine the extent to which the glue derives from non-human or human assets. Second, to the extent that the theories are static theories (in that they assume a non-human asset or glue already exists), we provide evidence as to the stage of a firm at which the glue emerges or "sticks" and how the “glue” evolves over a firm’s life cycle.

We also relate our results to theories of the firm that emphasize the existence of specific assets or resources that are critical to the firm's evolution and growth. In particular, Wernerfelt (1984) and Rajan and Zingales (2001b) focus on critical resources. A critical resource may be a person, “an idea, good customer relationships, a new tool, or superior management technique." According to these theories, a "firm is a web of specific investments built around a critical resource or resources... At some point, the critical resource becomes the web of specific investment itself.” [Zingales (2000)]. One can interpret this latter statement as something of a dynamic theory. By examining firms' resources (non-human and human assets) early in their lives and over time, we shed light on the nature of critical resources and the periods in which they are critical.

The theories above (as well as others such as Hart and Moore (1994)) also have implications for how rents are divided between providers of human (founders) and non-human capital and the ability of firms to raise outside financing. When specific human capital is more crucial, these models suggest that the specific human capital will capture more of the rents and make it more difficult to finance firms. With our data, we estimate the magnitude of the rents retained by specific human capital (founders) and the relation of those rents to the nature of the firms' assets. 
This analysis also sheds light on the "new firms” described in Zingales (2000) and Rajan and Zingales (2001a). They argue that today's new firms differ from the old, traditional firms of the (early) $20^{\text {th }}$ century. Old firms are "asset-intensive and highly vertically integrated ... [their] boundaries are clear cut and sufficiently stable that one can take them for granted." New firms, on the other hand, tend to be "nonvertically integrated, human capital intensive organizations operating in highly competitive environments.” Rajan and Zingales (2001a) argue that alienable assets - assets that can be assigned or pledged to other firms - have become less important relative to human capital and inalienable assets (e.g., business processes or knowledge). In fact, Zingales (2000) suggests that in today’s corporations "human capital is emerging as the most crucial asset.”

Related to the theoretical questions concerning the role of human and non-human capital assets is an old and ongoing debate among venture capitalists (VCs). Some VCs believe that the company's business and market are the key determinants of success while others believe that the key determinant is the company's management team. While VCs try to invest in companies with both strong businesses and strong management (see Kaplan and Strömberg (2004)), different VCs claim to weigh one or the other more heavily at the margin. For example, Donald Valentine of Sequoia Capital, the VC investor in Cisco, is a well-known proponent of the business / market view. Others favor the best available management team view. Quindlen (2000) discusses these two views from the VC perspective (p. 33-35). This debate is often characterized as whether one should bet on the jockey (management) or bet on the horse (the business / market).

Our results can be summarized as follows. The companies in our sample experience dramatic growth in revenue, assets, and market capitalization, but do not become profitable. While the companies grow dramatically, their core businesses appear remarkably stable. Only one firm changes its core line of business in the sense that the company produces a different product or service, or abandons its initial market segment to serve a different one. Rather than changing businesses, firms typically maintain or broaden their offerings within their initial market segments. The firms also sell to similar customers and compete against similar competitors in the three stages of the life cycle we examine. This suggests that the firms' business lines become fixed or elemental at a relatively early stage in a firm’s life cycle. 
Almost uniformly, firms claim that they are differentiated by a unique product, technology, or service at all three stages of the life cycle we examine. At the same time, however, the stated importance of expertise (which one might interpret as specific human capital) declines. Roughly half of the firms stress the importance of expertise at the business plan while fewer than $15 \%$ do so by the IPO and third annual reports.

With regard to non-human capital assets, firms stress the importance of proprietary intellectual property (IP), patents, and physical assets in all three stages. Patents and physical assets become increasingly important over time.

While the points of differentiation, alienable assets, customers, and competitors remain relatively constant, the human capital of the sample firms changes more substantially. At the time of the annual report, one-half of the CEOs at the business plan remain; only one-quarter of the next four top executives remain.

At this point, the results provide some insight into the Hart-Moore-Holmström view that a firm must be organized around non-human capital assets. Consistent with this view, we find that non-human capital assets form very early in a firm's life. Identifiable lines of business and important physical, patent, and IP assets are created in these firms by the time of the early business plan, are relatively stable, and do not change or disappear as specific human capital assets turn over.

This should not be interpreted as saying that specific human capital is unnecessary or unimportant. Obviously, a specific person has to have the initial idea and start the firm. Proprietary, but non-patented intellectual property is indeed critical to many firms. In contrast to non-human assets, however, the importance of specific people and initial expertise diminishes early in the firm's life cycle. Once the firm's non-human assets are established, it seems possible (and not unusual) to find other people to run the firm. ${ }^{2}$

These findings also have implications for the critical resource theories. The early emergence and stability of non-human assets are consistent with those assets being critical resources. The instability of the human assets suggests that to the extent that the initial critical resource is a specific person or founder, the "web of specific investments built around the founder(s)" itself becomes the critical resource relatively early in a firm’s life.

\footnotetext{
${ }^{2}$ For evidence consistent with this, see Bertrand and Schoar (2003).
} 
Our cross-sectional analysis provides further support to our interpretations of the Hart-MooreHolmström and critical resource theories. Firms with more alienable assets at the time of the business plan have substantially more human capital turnover over time. Again, this suggests that specific human capital is more critical before alienable assets have formed.

Our results also are consistent with recent theoretical work by Aghion, Dewatripont, and Stein (2005). Their model studies the tradeoffs between academic and private sector research. Based on control right considerations, they predict that once an idea becomes the property of a private firm (rather than an academic institution), it will be developed along relatively narrow lines.

From a practitioner perspective, we interpret the greater stability of the lines of business in our sample relative to that of management teams as favoring the business / market view of VC investing over the best available management team view. The results suggest that VCs are regularly able to find management replacements or improvements for good businesses. At least in our sample, we do not find cases in which VCs invest in good managers who move the firms into different businesses.

We then consider the division of rents. Using ownership stakes just before the IPO, we estimate the percentage of value that founders retain for their ideas rather than for incentive purposes. For their human capital assets specific to the company, our estimates suggest that founders retain from $10 \%$ to $19 \%$ of the value created by the firm. Regardless of whether these estimates are interpreted as small or large, they appear to be much lower than those for an earlier time period in Baker and Gompers (1999). This finding raises some doubt regarding the claim in Zingales (2000) that more recent, “new” firms are more dependent on specific human capital and, therefore, should allot a greater fraction of the value created to founders.

We view this study and methodology as an early empirical step in studying the nature and evolution of firms. While we believe that the results are novel and useful in interpreting theories of the firm, we acknowledge that the sample is indeed a special one in that the firms are all VC-funded and eventually went public. There are two reasons we chose to study this sample. First, we were able to obtain a relatively large data set. Second, as we discuss in the paper, VC-funded firms represent a substantial fraction of all IPOs (at least 39\%) and a higher fraction of all start-ups that ultimately go public. 
At the same time that this is an economically important sample to study, there are two reasons why the results may be special to this sample. First, VCs may choose to fund only those companies in which specific human capital is relatively unimportant. Zingales (2000) argues that VCs will invest in and organize firms such that the organization is not too dependent on any specific entrepreneur or individual. Kaplan and Strömberg (2003) find that VC contracts are carefully designed to give the VCs sufficient control rights to organize firms and replace founders and management when appropriate. Second, VCs may have special skills that can be interpreted as specific human capital. Hellman and Puri (2000 and 2002) find that VCbacked firms introduce products and professionalize management more quickly than non-VC-backed firms. This type of human capital may substitute for the human capital of a specific founder. A logical avenue for future research is to consider whether our results hold for non-VC backed firms.

Our work is closely related to three other research efforts. Bhide (2000) studies 100 companies from Inc. Magazine’s list of 500 fastest growing companies in 1989. Based on interviews with founders, Bhide finds that over $70 \%$ of those companies are founded by people who replicated or modified an idea encountered in their previous employment. They do relatively little planning before starting the business. Partly as a result, these companies frequently adjust their business plans as they operate. Bhide contrasts these companies to VC-funded companies which he argues are more likely to "have innovative ideas and a verifiable record of ... achievement (p. 111).” Our study complements his in that we focus on VC funded companies. In addition, we focus more on the nature of the initial attributes of a company, how those attributes evolve, and how those attributes affect outcomes.

Our work also is related to the papers that emerged from the Stanford Project on Emerging Companies (Baron and Hannan (2002), Baron et al. 1999, Baron et. al. 2001; Hannan et al. 2000; and Hellman and Puri (2000 and 2002)). Like we do, they study a panel of young firms - high technology firms in Silicon Valley - but they ask a different set of questions. Baron and Hannan (2002) summarize the findings of their papers as showing that initial employment models are important and tend to persist. When they are changed, employee turnover increases and performance declines. 
Finally, Santos and Eisenhardt (2004) provide a case-based study of five new information technology firms. They study how those firms attempted to claim their initial market, how they demarcated that market, and how they used acquisitions to consolidate that market.

The paper proceeds as follows. Section I describes our sample. Section II describes the initial financial characteristics, business idea, point(s) of differentiation, assets and technology, growth strategy, customers, competitors, strategic alliances, management, ownership structure, and board of directors of the sample firms and their evolution. Section III presents our cross-sectional estimates. Section IV summarizes and discusses our results.

\section{Sample}

The sample consists of forty-nine companies that went public in an IPO and for which we obtained an early business plan or business description at the time of a VC financing. We obtained twenty-nine of the companies from the sample of VC financed companies in Kaplan and Strömberg (2003). We obtained an additional twenty companies by asking several VCs to provide business plans of companies they had financed that had subsequently gone public.

For all of the companies in the sample, we have copies of the business plans and / or the venture capitalist investment memos that describe the company at the time of venture capital funding. (We do not find meaningful differences in the two types of documents. Accordingly, in what follows, we drop the distinction and collectively refer to them as business plans.) We are able to identify the early (and often initial) characteristics of these firms. For all of the sample companies, we also have detailed descriptions of the companies at the time of their IPOs. We obtain IPO descriptions from S-1 registration statements and 424B prospectuses filed with the SEC. When available, we collect the company's annual report that is closest to 36 months after the IPO, a period roughly equal to the time from the business plan to the IPO. If an annual report is not available 36 months after the IPO, we collect the latest annual report that is at least 12 months after the IPO. We obtain annual report descriptions from SEC form 10-K filings. 
For ten companies, we do not record an annual report observation: three companies were taken over and one went bankrupt less than one year after the IPO; five companies are public, but have not filed an annual report more than twelve months after the IPO; one company is a Canadian firm which does not file annual reports with the SEC. We retain the business plan and IPO observations for all forty-nine firms.

\section{A. Description}

Table 1 presents summary information for our sample. The median company is 24 months old as of the business plan, so these documents describe the companies when they are young. As we document below, these companies are early stage businesses at the time of the business plan; the median company had no revenue in the most recently ended fiscal year at the time of the business plan.

The median time elapsed between the business plan and the IPO in our sample is 34 months, with a further median gap of 33 months between the IPO and the annual report observations. The IPO observation is therefore quite close to the midpoint of the business plan and annual report observations. The median total time elapsed is 63 months; the average is 68 months. Since the median total time elapsed is more than twice the median company age at our first observation, our 3 observations should be sufficiently spaced in time to have the opportunity to observe meaningful time series variation in company characteristics.

Of the 48 companies whose founders we were able to identify, 21 have one founder, 16 have two cofounders, and 11 were co-founded by three or more individuals.

The frequency distributions in table 1 show that the bulk of the sample companies were founded in the early-to-mid nineties while the business plans describe the companies in the mid-to-late nineties. Thirtyone of the forty-nine IPOs took place in 1998, 1999, or 2000, at the height of the technology boom. The industry breakdown of our sample is heavily weighted towards high-technology firms: 17 in biotech, 15 in software/information technology, 3 in telecom, 5 in healthcare, 5 in retail, and 4 in other industries, of which 3 are high-tech companies. The time frame of the sample, therefore, also corresponds to the period in which “new firms” emerged as described in Zingales (2000) and Rajan and Zingales (2001b). 
Finally, table 1 shows our companies’ status as of July 31, 2005. 27 are still active, independent companies. 15 have been acquired, and 7 have failed and gone bankrupt.

\section{B. Sample selection issues}

In this section, we discuss potential selection issues. Most importantly, our sample includes only VC-backed firms because it is from our VC contacts that we were able to obtain the necessary data. VCbacked firms represent only a small fraction of all entrepreneurial firms and are unlikely to be representative of the typical entrepreneurial firm because of various constraints, conditions, and practices governing venture capitalists' selection of their portfolio companies. For example, VCs typically invest several million dollars in any given company. For such an investment to make sense, the VC must expect the portfolio company to be able to use the capital and offer a return that is a multiple of the VCs' investment. Typical mom-and-pop stores or other low-risk, low-reward start-up firms are not in a position to do either of these.

Even though they are not representative of all start-ups, VC-backed start-ups are an important subject for study because they tend to include the most promising start-ups that end up having a disproportionate impact on the economy. In particular, VC funded companies typically comprise a substantial fraction of young companies that go public in any given year. According to the National Venture Capital Association (2004), about 39\% of all IPOs from 1993 to 2003 are VC-financed companies. This understates the fraction of IPOs of young companies that are VC financed because some of the non-VC financed IPOs are mature companies such as divisions of public companies (spin-offs or equity carve-outs) or companies returning to the public markets after having gone private. We discuss results that may be special to VC-backed firms as we come to them in the paper and in the conclusion.

Among the VC-financed universe of firms, our sample of portfolio companies and financings is not a random sample in that we obtained the data from VC firms with whom we have a relationship. The 29 companies from Kaplan and Strömberg (2003) are taken from a sample of 119 VC-backed companies. As Kaplan and Strömberg (2003) do not find any obvious bias in the 119 companies, we do not think there are any obvious biases in the 29 companies that went public. The additional 20 companies provided by VCs at 
our request represent those companies that the VCs had financed and subsequently taken public. The VCs who agreed to participate provided all the relevant business plans they could find so there should not be a selection bias for any particular VC.

Finally, it is possible that there is some bias in the VCs who decide to participate. Such a bias would affect our results only if those VCs invest in companies with atypical initial assets that evolve in an atypical way. For example, the VCs in our sample may focus on one of non-human or human capital over the other. Although this is possible, we have no reason to believe the participating VCs are atypical in this sense.

The industries of the sample firms are representative of the industries that VCs invest in. At the same time, however, investments in biotech and healthcare are over-represented - $45 \%$ of our sample versus roughly $20 \%$ of the overall VC market - while investments in software, information technology and telecom are under-represented relative to the overall VC market (see National Venture Capital Association (2004)). Because biotech firms, in particular, are oversampled and potentially different from other types of companies, we report most of our results separately for biotech and non-biotech firms.

\section{Results}

\section{A. Financials and Employees}

Table 2 summarizes the financial and employment histories of our firms. Consistent with describing the firms at an early stage, revenues, assets, and employees of the sample firms are small at the time of the business plans. They increase by orders of magnitude between the business plan and the annual report. Negative profits are the norm at the business plan. Despite increases in revenues, assets, employees, and market capitalization, the median firm does not become profitable through the post-IPO annual report.

\section{A.1 Revenue}

At the business plan, the median company reports no revenue in the prior fiscal year. Average revenue is $\$ 5.5$ million, reflecting seven companies with revenues over $\$ 10$ million. 
At the IPO, the median and average revenue figures increase dramatically to $\$ 7.2$ million and $\$ 40.5$ million. Four companies go public with no revenue in the latest fiscal year; another nine have less than \$1 million in revenues. By the annual report, revenues increase by another order of magnitude, to a median of \$35.1 million and an average of \$179.0 million. The huge percentage changes are consistent with the revenue levels. Both the biotech and non-biotech firms experience substantial growth, but the biotech firms begin from a smaller base.

The extremely rapid revenue growth exhibited by our sample suggests that they are successful in supplying products and services to quickly growing segments of the economy. We believe that the evolution of company characteristics we consider in this paper is particularly interesting in light of this rapid growth. Rapid revenue growth into the millions of dollars per year is characteristic, according to Bhide (2000), of the types of start-ups VCs try to select.

\section{A.2 Employees and revenue per employee}

The median company has 22 employees at the business plan, 124 at the IPO, and 378 at the annual report. Because retail companies tend to be more labor-intensive than others in our sample, panel B provides employee statistics excluding the five retail companies. The median number of employees for non-retail companies is 18, 102, and 256 at the business plan, IPO, and annual report.

Revenue per employee also increases dramatically over time, from a median of 0 at the business plan to $\$ 50.5$ thousand at the IPO and $\$ 124.6$ thousand at the annual report. The increase for the non-retail subsample is similar to that of the overall sample.

\section{A.3 Assets}

Asset growth for the sample parallels revenue growth, suggesting the need for large investment outlays to generate such rapid growth. The median company’s book assets at the business plan, IPO, and annual report are, respectively, \$2.6 million, \$19.6 million, and \$96.7 million; the average company’s are \$5.9 million, \$44.3 million, and \$274.9 million. 


\section{A.4 Earning Before Interest and Taxes (EBIT)}

Our companies are unprofitable at the time of the business plan - when we can measure profitability. The losses increase from the business plan through the IPO and annual report. This is consistent with the patterns for recent IPOs described in Fama and French (2003), particularly for young firms. The median company's EBIT for the fiscal year prior to the business plan, IPO, and annual report are, respectively, \$0.78 million, -\$6.7 million, and -\$25.6 million. Bhide (2000, p. 155) writes that "the financial projections of VC-backed firms usually anticipate negative cash flows for several years.” These projections are borne out in our sample -- only 17\%, 18\%, and 15\% of firms, respectively, are profitable at the business plan, IPO, and annual report. The patterns of medians are similar for both biotech and non-biotech firms. However, biotech firms are less likely to be profitable, with $13 \%, 6 \%$, and $0 \%$, respectively, profitable at the business plan, IPO, and annual report.

\section{A.5 Market capitalization and market-to-assets ratio}

We calculate market capitalization at the business plan as the value of the company after a VC financing that occurs within six months of the date of the business plan. Market capitalization at the IPO is calculated as the first trading day's closing price times the number of shares outstanding following the offering. Market capitalization at the annual report is the average of the high and low stock prices during the last quarter of the year covered by the annual report times the number of shares outstanding as of the issue date of the report. We do not have a market capitalization figure at the annual report for one company whose shares were delisted.

The median market capitalization increases sharply from \$17.9 million at the business plan to \$232.4 million at the IPO, and then declines to $\$ 176.9$ million at the annual report. The corresponding median market-to-assets ratios are 5.4, 13.9, and 1.8. The market capitalization figures indicate a roughly tenfold increase in value from business plan to IPO, a period of roughly 3 years. These companies, despite their 
negative profits, are highly valued. The decline in the market capitalization after the IPO is consistent with (and likely driven by) the technology stock "bust” from 2000 to 2002.

\section{B. Business}

\section{Line of business}

Panel A of table 3 presents a description of each company's business as described in each of the three relevant documents. For each company, we determine if the description of the business changes from one point in time to the next. We categorize the changes in two ways. First, we consider whether firms change their line of business. The line of business changes if the firm sells to a completely different set of customers or if the firm markedly changes the products or services it offers. Second, we consider whether firms broaden, narrow, or maintain their initial business model or line of business. If Apple Computer were in the sample, we would classify Apple as having the same line of business it had when it started - personal computers sold to the same customers - but with a line of business that had broadened.

These comparisons admittedly have a subjective component to them. We report the individual descriptions to give the reader a sense of the type and magnitude of these changes. The descriptions have been coarsened to protect the anonymity of the portfolio companies and VC firms. The descriptions in the business plans and other documents are always at least a paragraph and usually much longer. We base our measurements and conclusions on the more detailed descriptions to which we have access.

At the end of panel A, we report the percentage of companies that fall into each category. One notable result emerges quickly in this table. While we observe broadening or narrowing of the business, only one of the forty-nine firms in our sample changes its line of business. For example, a biotech firm may decide to narrow its focus from disease prevention in general to focusing on a specific type of vaccine (company 36). Or an e-commerce firm might broaden its e-commerce offerings to include more services and infrastructure offerings (company 31). We do not observe any of the firms undertaking acquisitions unrelated to the original business. We also do not observe radical shifts in focus such as a medical equipment company switching to drug development. Company 49 undergoes the greatest change, moving 
from offering a new computing platform to a new operating system to a suite of software programs, each time dropping the previous idea, but even in this case there is a general focus on personal computing.

This result suggests that the initial business lines and / or the accompanying attributes of those businesses do not change and, therefore, appear to be core to our sample firms. The result is consistent with the assertion of Bhide (2000, p.155) that "VC-backed firms face less pressure to change their plans than do [other] promising start-ups.”

For the most part, companies tend to broaden or at least not reduce their offerings within markets. For the 48 companies that did not change their line of business, panel A of table 3 shows that only 13\% narrowed their lines of business between the business plan and IPO, 8\% narrowed between the IPO and annual report, and only $13 \%$ had narrower offerings at the annual report than at the business plan. Over the corresponding periods, $42 \%, 42 \%$, and $37 \%$.of the firms keep their offerings roughly the same, while $46 \%$, $50 \%$, and $50 \%$ broaden their offerings.

Non-biotech firms differ from biotech firms in that non-biotech firms rarely narrow their line(s) of business while biotech firms are more likely to narrow and less likely to broaden their line(s) of business.

\section{Origin of business idea}

Panel B of table 3 classifies the origin of the business idea. Of the 34 companies for which we were able to find a definitive source, 5 were formed as spin-offs or joint ventures of already existing companies, 15 were started to exploit an idea the founder(s) had as a result of previous jobs, and 14 were based on academic research. Again, there is a clear difference for biotech firms which are more likely to be based on academic research while non-biotech firms are most likely to be based on ideas from previous jobs. ${ }^{3}$

\footnotetext{
${ }^{3}$ See Gompers et al. (2005) who study the background of founders in a large sample of venture-backed start-ups. The margin between forming new ventures as start-ups (entrepreneurship) or within established firms (intrapreneurship) has been analyzed to some extent (e.g., Gromb and Scharfstein 2002). Also, see Aghion et al. (2005) who study the role of non-profit academic institutions in innovation.
} 


\section{Business strategy}

Panel B also classifies our companies’ business plan strategies into the categories of Baron, Hannon, and Burton (1999). Innovators are companies striving to create novel products for new, undeveloped markets. Enhancers are companies striving to improve upon products for already developed markets. Marketers are companies whose core competency lies in the marketing, distribution, and sales of their products. Technology/marketing hybrids are companies that share characteristics of the marketers as well as innovators/enhancers. Cost refers to companies who compete primarily by providing their product at low cost. We classify 24 firms (49\%) as innovators, 11 (22\%) as enhancers, 5 (10\%) as marketers, 6 (12\%) as technology/marketing hybrids, and $3(6 \%)$ as cost. This distribution is similar to that of Baron et al.’s (1999) larger sample of 149 companies: 50\%, 19\%, 13\%, 11\%, and 7\%, respectively.

\section{Point of differentiation}

In table 4, we classify how the sample firms differentiate themselves from their competitors over the sample period. We rely on the distinguishing characteristics stated by the companies themselves.

We mention two caveats in interpreting these results. First, it is possible that the business plans are overly positive because the entrepreneurs are marketing their companies to the VCs. While possible, we do not find any appreciable difference between business plans (prepared by the firms) and investment memos (prepared by the VCs) with respect to the variables we analyze. Second, it is possible that the descriptions in the public documents - IPO prospectuses and Annual Reports - differ from those in the business plan because of legal liability concerns rather than business reasons.

By far the most important factor, cited by $100 \%, 98 \%$, and $92 \%$ of companies, respectively, at the business plan, IPO, and annual report, is a belief that the company offers a unique product and/or technology. A small number of firms - $6 \%, 12 \%$, and $13 \%$ - cite the comprehensiveness of their products as differentiating at the three relevant dates. 
Customer service becomes an increasingly important source of differentiation over time, increasing from $8 \%$ to $16 \%$ to $26 \%$ as a differentiating factor, respectively at the business plan, IPO, and annual report. Not surprisingly, customer service is relatively more important in the non-biotech firms.

Alliances and partnerships are of modest importance throughout with $12 \%, 12 \%$, and $8 \%$ of the firms referring to them at the business plan, IPO and annual report.

At the business plan, $45 \%$ of companies cite the expertise of their management and other employees as distinguishing characteristics. This suggests that specific human capital plays an important role in the early life of many of these companies. The percentage of firms that cite expertise declines to $14 \%$ at the IPO and $13 \%$ at the annual report. This result is suggestive of an increasingly important role for non-human capital compared to specific human capital as companies mature. There is not much difference in the importance of expertise between biotech and non-biotech firms.

A small number of firms - 4\%, 2\%, and 5\% - also cite scientific advisors, another human capital related resource - as important.

Finally, a small number of firms $-6 \%, 8 \%$, and $8 \%$ - cite reputation as important. This may reflect human or non-human capital reputation.

The transition percentages shown in table 4 indicate that self-reported company distinguishing characteristics are generally stable over time. The columns labeled "yes to no" and "no to yes" show the percentage of firms for which a given characteristic was (was not) cited at one time but was not (was) cited at a later time. The one exception is the large reduction in firms citing management or employee expertise as a differentiating characteristic from the business plan to the IPO.

Overall, self-reported distinguishing characteristics suggest that non-human capital assets are more important than specific human capital assets initially, and that the relative importance increases over time.

\section{Assets and Technology}

In table 5, we describe the types of assets owned by our firms. We note whether each firm mentions patents, physical assets, and / or non-patented intellectual property as important or central to the business. 
For example, while all firms have some physical assets, those physical assets do not necessarily differentiate or add value to the business. In particular, specific physical assets are generally not critical to software firms.

We classify the patents and physical assets as alienable assets because they can potentially be sold or assigned to other companies. We classify non-patented intellectual property as some kind of process, technique, or knowledge that the company believes is an important asset, but is not patented or assignable. Such non-patented intellectual property may or may not be tied to specific human capital.

A firm can have both patented and non-patented intellectual property. In the table, when we refer to proprietary intellectual property, this includes both patented and non-patented intellectual property. The distinction does not affect the percentages because all firms with patented intellectual property also claim to have non-patented intellectual property.

Table 5 indicates that patents and physical assets become increasingly important from the business plan to the IPO to the annual report. At the business plan, 29\% of companies own or are the exclusive licensees of patents; at the IPO, 49\%; and at the annual report, $62 \%$. While patents and exclusive licenses are most important for biotech firms, they also are important for non-retail, non-biotech firms.

Physical assets are relatively unimportant for biotech firms and always important for retail firms. Physical assets become increasingly important for non-retail, non-biotech firms, going from $9 \%$ to $18 \%$ to 29\% from business plan through annual report. When patents and physical assets are combined as alienable assets, we find that $43 \%, 67 \%$, and $82 \%$ of the sample firms have such assets, respectively, at the business plan, IPO, and annual report.

Proprietary intellectual property is important for almost all of the non-retail firms - both biotech and non-biotech. Intellectual property, therefore, whether patented or not, is substantially more important than physical assets. This implies that the non-retail companies in the sample are based largely on ideas or knowledge rather than physical capital. This is consistent with arguments in Zingales (2000) that firms are increasingly defined by intellectual rather than physical capital. 


\section{E. Growth strategy}

In table 6, we document the elements and evolution of the companies’ growth strategies. At all times, the firms are strongly oriented towards internal growth. The most cited strategies at the business plan, IPO and annual report are to produce new or upgraded products (59\%, 82\% and $72 \%$, respectively), followed by obtaining additional customers through increased market penetration or market leadership (49\%, 71\%, and 56\%, respectively). Companies also plan to expand geographically (20\%, 43\%, and 21\%, respectively).

All three types of internal growth peak at the time of the IPO. It is worth noting that the emphasis on internal growth and, particularly, new products, is consistent with the result in table 5 that these companies rely heavily on differentiated products and technologies.

External growth through alliances and partnerships or through acquisitions becomes relatively more important over time. At the business plan, 29\% and 2\%, respectively, of the firms look for growth through alliances or acquisitions. By the time of the third annual report, this has increased to $51 \%$ and $28 \%$, respectively. At all times, biotech companies are more likely to pursue alliances - typically with large pharmaceutical companies for the development, testing, and / or distribution of their products.

The transition percentages show that growth strategies tend to broaden between the business plan and IPO. The percentages in the "no to yes" column are all considerably larger than those in the "yes to no" column. By the IPO, companies are trying to grow along more dimensions than at the business plan. Surprisingly, growth strategies seem to narrow somewhat between the IPO and annual report. Except for acquisitions, the percentages in the "yes to no" column are larger than those in the "no to yes" column. Two explanations are possible. Perhaps some of the growth strategies cited at the IPO were unsuccessful and, therefore, abandoned. Another explanation is increased conservatism due to the decrease in market capitalization and net income.

\section{F. Customers}

In table 7, we describe the evolution of our companies' customers. At the business plan, only $47 \%$ actually have customers; by the IPO, 90\% have customers; and by the annual report, 95\% have customers. 
At all stages, biotech firms are less likely to have customers than the non-biotech firms. All of these percentages are consistent with the revenue results presented in table 2.

Roughly $85 \%$ of the sample companies target businesses as customers while $15 \%$ target consumers as customers. These percentages are stable through all stages, consistent with the results on the stability of the business model in table 3 .

We characterize the evolution of company customer bases as broadening, narrowing, or staying about the same. An example of a broadening customer base would be a company that targets its products to medium-sized businesses at the business plan, but targets its products to both medium-sized and large (Fortune 500) companies at the IPO. The majority of the companies address a similar customer base over time, consistent again with the stability of the business models in the sample. Roughly one-third of the firms broaden their customer bases. About one-quarter broaden from business plan to IPO and another 15\% broaden from IPO to annual report. A small fraction of the sample firms narrows their customer base.

These results suggest that the dramatic revenue increases in table 2 are primarily driven by selling more to an initial customer type either through increased market penetration or by selling additional products. The revenue increases are likely driven secondarily by selling to new types of customers.

\section{G. Competitors}

Table 8 describes the competition faced by the sample companies. At the business plan, $84 \%$ of the companies note that they face competition in their target markets. Typically this competition includes other startups as well as established firms. Of the other $16 \%$ of companies, $10 \%$ do not mention competition while 6\% (three companies) claim that their product or market niche is so unusual that they face no real competition. All 49 companies note that they have competition by the IPO.

The type of competition named remains fairly stable with $56 \%$ of the firms claiming to face similar competitive threats over all three stages. Roughly $40 \%$ see a broadening in the types of companies they compete with while one company sees a narrowing. Again, this result seems consistent with the stability of the business model found in table 3 . 


\section{H. Strategic alliances and other partnerships}

The use of strategic alliances provides some evidence regarding firm boundaries because such alliances allow firms to contract to cooperate and share resources without merging. Table 9 summarizes the use and evolution of strategic alliances and other similar partnership arrangements by the sample companies.

The use of strategic alliances increases from business plan to IPO and then is approximately flat from IPO to annual report. The increase is particularly large for the biotech firms. At the business plan, 35\% of the companies mention strategic alliances. This increases to $67 \%$ at the IPO and $69 \%$ at the annual report. For biotech companies, $18 \%, 82 \%$, and $82 \%$, respectively, have alliances at the business plan, IPO and annual report; for non-biotech companies, the corresponding percentages are 44\%, 59\%, and 64\%. Among companies with strategic alliances, the median (average) number of alliances increases over time from 2 (2.2) at the business plan to 3 (3.3) at the IPO to 4 (5.4) at the annual report.

Although strategic alliances are not as common before the IPO, those that do exist are more stable through the IPO. Among companies with strategic alliances at the business plan, a median (average) 67\% (60\%) of those alliances still exist at the IPO. Among companies with strategic alliances at the IPO, only $42 \%$ (46\%) survive to the annual report. Overall, only a median 20\% (average 39\%) of alliances at the business plan still exist at the annual report.

\section{Management}

The previous tables have focused largely on the non-human capital elements of the sample companies. We now turn our attention to the human capital elements of the firms.

Panel A of table 10 characterizes the top five executives described in the business plan, IPO prospectus, and annual report. At the time of the business plan, the management teams are incomplete, particularly the biotech firms: six of the companies (12\%), five of which are in biotech, do not have a CEO; only $42 \%$ list a chief financial officer (CFO) as one of the top five executives; and only $38 \%$ list a sales or 
marketing executive (CMO). Consistent with the importance of technology, 77\% of the firms list a Chief Scientist, Chief Technical Officer, Vice President of Engineering (CTO), or similar as a top five executive.

By the time of the IPO and annual report, CFOs have become increasingly important, with $80 \%$ and 85\% of the companies listing a CFO as a top five executive. The importance of sales and marketing remains fairly constant over time with 38\%, 37\%, and 41\% of companies having a VP of marketing or similar as a top five executive at the business plan, IPO, and annual report. Biotech companies are much less likely to have such a person as a top five manager. The importance of a chief technology or science officer is stable at the IPO (at 77\%), but declines substantially (to 47\%) by the annual report

Panel A also provides information on the involvement of founders. Founders are heavily involved with the companies at the time of the business plan. We can identify a founder as the CEO of $77 \%$ of the 43 companies with a CEO (33 companies). We also can identify a founder as being on the board in $92 \%$ of the companies in which the founder is not the CEO and we have board information. A founder is a top five manager or on the board of all 47 companies for which we have board and management data.

Involvement of founders declines steadily over time. By the time of the IPO, only $57 \%$ of the CEOs are founders while $92 \%$ of the firms still have a founder as a top executive or a director. By the time of the annual report, $46 \%$ of the CEOs are founders while only $72 \%$ of the firms still have a founder as a top executive or a director. This suggests that over time, founders move from operating positions to board positions to no involvement with the company.

Panel B describes the previous backgrounds of the top five executives listed in the business plan. We characterize $42 \%$ of these executives with a background in general management, $25 \%$ in technical or technology management, $16 \%$ in science or other technical jobs, $9 \%$ with marketing backgrounds, and $8 \%$ with backgrounds in finance or accounting. The biotech company executives are more likely to have a technical management or science background while the non-biotech company executives are more likely to have a general management background. Nevertheless, for both types of firms, it seems, then, that a fairly broad set of skills are employed to manage our sample companies, even when they are very young. These companies employ the skills of experienced professionals fairly early on. 
In panel C, we address the stability of human capital in more detail. CEO turnover is relatively low from the business plan to the IPO with $84 \%$ of the CEOs remaining in place. Turnover of the other top executives is greater with only 55\% remaining in place from business plan to IPO. Turnover of both the CEO and the other top five executives is more common after the company has gone public. Only 59\% of the CEOs retain their jobs between the IPO and the annual report while only $36 \%$ of the other top five executives remain the same. Overall, therefore, turnover is substantial. From the business plan to the annual report, exactly $50 \%$ of the CEOs and only $25 \%$ of the other top five executives remain the same.

The third row of panel $\mathrm{C}$ reports whether the former CEOs remain with the company in some capacity. At the IPO and annual report, respectively, only $29 \%$ and $11 \%$ of the former CEOs remain with the firms, suggesting, for the most part, that former CEOs leave the sample companies. The fourth row of panel C, presents a similar calculation for the former next four executives. To an even greater extent, those former executives leave the sample companies.

The relatively high incidence of founder and early executive departures is interesting. It may indicate that those founders and executives are particularly good at starting companies / providing early critical resources. Once the non-human capital is sufficiently established, these founders go on to do the same thing at other companies. We ascertain the extent to which this is true in by considering what the departing founders and executives do after leaving the firm.

We search for evidence of subsequent job or founder history in another young company for the departing executives in the CapitalIQ, VentureEconomics, and VentureOne databases. If they do not appear in these databases, it is unlikely that they went to another VC-backed or high profile young company. The results are in panel $\mathrm{D}$ of table 10 . The first part of panel $\mathrm{D}$ shows that we can identify subsequent jobs or activities for roughly half of the departing founders and non-founders. The second part of panel D indicates that relatively few of these individuals subsequently found new companies. The highest percentage is $17 \%$, representing one founder who departed between the business plan and the IPO, and subsequently founded another company. The third part of panel D reports the percentage of departing founders and non-founder 
top executives who become top executives of other young companies. A larger fraction, roughly one-third, of founder and non-founders go on to do so.

These results in panel $\mathrm{D}$, therefore, indicate that relatively few of the departing founders and executives found new companies while a greater (but minority) percentage repeat their experience in working for young companies and, potentially providing early critical resources. We report these findings with the caveat that they may understate the true percentages because not enough time has elapsed for some of the individuals to emerge in other companies.

\section{J. Ownership}

In the previous we described the evolution of human capital. In this section, we consider the rewards and incentives of the providers of that human capital. Table 11 summarizes company ownership. Ownership data at the business plan reflects 33 firms as we do not have ownership data at that time for 16 firms.

Panel A shows the evolution of ownership by the founders (taken as a group) and the CEO at the different company stages. We report ownership at the business plan immediately after the VC financing for which we have data. We report ownership both immediately before and immediately after the IPO.

Founder ownership declines sharply from a median of $28.9 \%$ at the business plan to $12.4 \%$ just before the IPO to $8.8 \%$ immediately following the IPO. Because founders typically are not allowed to sell any shares until six months after the IPO, this suggests that founders give up a substantial fraction of their ownership stakes in order to attract VC financing and / or outside management talent. Founder ownership continues to decline over the company's public life, to a median $5.3 \%$ at the annual report. This decline reflects founder stock sales as well as issuance of additional stock.

CEO ownership also declines as the firm ages: the median CEO owns $15.9 \%$ of the company at the business plan, 6.7\% pre-IPO, 5.4\% post-IPO, and 3.6\% at the annual report. CEO ownership declines by a median 38\% from the business plan to the pre-IPO. 
The six CEOs who are not founders own a median of $5.5 \%$ of the company at the time of the business plan. The twenty-one non-founder CEOs at the time of the IPO own a median of $4.2 \%$ of the company just before the IPO. One can interpret these results as indicating that VC-financed companies allocate roughly $5 \%$ of the company's equity to attract and provide incentives to an outside CEO.

Panel A also breaks out the companies by biotech and non-biotech firms. Biotech and non-biotech founders own roughly the same percentage of the companies at the business plan. At the time of the IPO, however, biotech founders own less of the firms than non-biotech founders. Biotech CEOs own less of the firms than non-biotech CEOs both at the business plan and at the IPO. These results suggest that specific human capital is less important in biotech companies. There are at least two possible explanations. First, it may be easier to patent or assign the intellectual property of these companies. Second, these companies may require more financial capital.

The CEOs in our sample own an average of $9.8 \%$ of the pre-IPO (7.5\% of the post-IPO) equity of the sample firms. This is less than the 19.1\% pre-IPO (14.0\% post-IPO) reported in Baker and Gompers (1999) for 433 VC-backed firms that went public between 1978 and 1987. Part of the reason for the difference is that our sample includes relatively more biotech firms which have relatively fewer founder CEOs. However, even for non-biotech firms, the CEO only owns 10.6\% pre-IPO (8.2\% post-IPO). Surprisingly, this suggests that human capital may have become less important rather than more important over time.

Panel B of table 11 reports how the ownership of the firm is divided immediately before the IPO. VCs, in exchange for financial capital and, potentially, their own human capital, own a median of 52.6\% of the median company at the IPO. Founders retain a median $12.4 \%$. When non-founders, CEOs own a median 4.2\%; non-founder managers other than the CEO collectively own a median 2.2\%. Business partners, such as original parent companies and strategic alliance partners, own none of the median firm and 3.8\% of the average firm. Others, which include non-VC investors and non-founder employees, collectively, own a median of 22.7\%. Panel B also indicates that the founders and management team have smaller equity positions in biotech firms than in non-biotech firms. 
The last column of panel B calculates the dollar value of the founders' equity stakes using the first trading day’s closing price, finding a median value of \$17.5 million and an average of \$103.3 million. The dollar value of non-biotech founders' holdings is substantially higher than those of biotech founders.

Using the ownership stakes just before the IPO in panel B, we can obtain three estimates of the percentage of value that founders retain that is not related to ongoing incentives. The first is the founders' average ownership percentage of $14.6 \%$ (median 12.4\%). This is an upper bound, because some of this ownership is present for incentive purposes and would be given to non-founding managers. It is also an upper bound because the founders may have contributed non-human capital.

The second estimate begins with the ownership of founders and the top five managers that equals an average of $20.3 \%$ (median $16.3 \%$ ). In the six cases in which there are no founders among the top five managers, their average ownership is $6.0 \%$ (median of $6.2 \%$ ). The $6.0 \%$ stake provides an estimate of how much equity is required to attract a new management team to replace the existing one. The $14.3 \%$ difference provides another upper bound estimate of the value of the specific human capital that the founders provided.

A third measure calculates the equity needed for ongoing incentives by adding the average ownership of non-founder CEOs, 5.0\%, to that of other non-founder, non-CEO top managers, 3.5\%, to get a total of $8.5 \%$. Subtracting this $8.5 \%$ from the ownership of founders and top five managers of $20.3 \%$ yields an estimate of $11.8 \%$ as the value of the specific human capital provided by the founders.

In an unreported regression, we regress pre-IPO founder ownership on a constant and a dummy variable equal to one if the founder is the CEO at the IPO. The coefficient on the dummy variable provides an estimate of the ownership needed for incentive purposes for the CEO. The coefficient is likely to be biased upward, however, because if the founder is still CEO, the CEO's value may be unusually high and the ownership may include some compensation for specific human capital. The constant term, therefore, can be considered a lower bound on compensation for the idea or specific human capital. In this regression, the constant term is $10.8 \%$.

Overall, the estimates in panel B suggest that founders retain $10.8 \%$ to $14.6 \%$ of the value of the preIPO equity for their human capital assets specific to the company. 
In estimating the value accruing to specific human capital, we have used the total market value of the firm's equity. This overstates the value created by the firm because it ignores the financial capital invested in the company, particularly by the VCs. Panel C of table 11 presents an analysis similar to that in panel B for pre-IPO ownership, except that it measures the founders' share of total value created before the IPO. We measure the total value created before the IPO as the value of the pre-IPO shares outstanding at the post-IPO stock price less the amount of outside financing raised by the firm before the IPO. The analysis assumes that the founders did not invest any money to obtain their shares and do not need to invest any money to exercise any options they may have. As a result, the analysis in panel $\mathrm{C}$ overstates the fraction of value accruing to founders (while panel B understates the fraction). One firm did not create any value - pre-IPO outside capital exceeded the value of the pre-IPO shares at the IPO price. We exclude this firm from the analysis.

Panel C indicates that the founders receive an average of 19.1\% (median of 14.4\%) of the value created. Again, this is an upper bound because some of this ownership is present for incentive purposes. The other two methods of calculating the value founders retain for non-incentive purposes generate estimates of $17 \%$ and $15.5 \%$.

The estimates and calculations in panels B and C indicate a range of $10.8 \%$ to $19.1 \%$ as the value that founders retain of the firm for their idea or initial contributions that is not related to ongoing incentives.

\section{K. Boards of directors}

Table 12 documents the size, composition, and turnover of the boards of directors of our companies. The median board size is 5 seats at the business plan, 7 seats at the IPO, and 7 at the annual report. Insiders, defined as founders and current or past company managers, hold a constant median of 2 seats at each of the business plan, IPO, and annual report. VCs hold a median of 2 seats at the business plan, 3 at the IPO, and 1 at the annual report. This pattern reflects additional VC investment between the business plan and IPO, and profit-taking once the company has issued shares to the public. Meanwhile, the board presence of non-VC outsiders, who are generally either industry experts and / or experienced executives of other firms, increases from a median of 1 seat at the business plan to 2 at the IPO to 3 at the annual report. 
Director turnover also increases after the company goes public. While $71 \%$ of directors at the business plan are still directors at the IPO, only 57\% of the directors at the IPO are directors at the annual report. Only $40 \%$ of the directors at the business plan remain at the annual report.

\section{Cross-sectional Analysis}

In this section, we present the results of two cross-sectional analyses.

First, we consider the relation of human capital turnover to the nature of a firm's assets. One can (loosely) interpret the theories of the firm considered above as predicting that founders and specific human capital will be less important or critical when a firm has built up its non-human capital. In table 13, we try to test this by estimating the likelihood of a founder remaining CEO after the business plan. In panel A, the dependent variable equals one if one of the founders is CEO at the IPO; in panel B, the dependent variable equals one if one of the founders is CEO at the annual report. (We obtain qualitatively similar results if we use CEO turnover, regardless of whether the CEO was the founder.) As independent variables, we use the results in table 5 and create three dummy variables that equal one if, respectively, alienable assets, physical assets, or patents, are cited as significant assets at the business plan. We also create a dummy variable equal to one if the firm has no patents and non-patentable intellectual property (IP) is significant.

The regressions show a clear pattern. Firms with more alienable assets at the time of the business plan have substantially more founder turnover over time. All of the relevant coefficients are negative; the majority, statistically significant. Again, this suggests that specific human capital is more critical before alienable assets have formed, consistent with both the critical resource and the Hart-Moore-Holmström theories. The strong cross-sectional relation also corroborates our interpretation of the descriptive data.

The presence of non-patentable IP at the business plan is also negatively related to the likelihood that the founder will be remain as CEO later on. One interpretation of this result is that even unpatented knowhow may be part of alienable organizational capital rather than tied to a specific founder. 
The regressions also include a number of controls whose signs are more difficult to interpret. The age of the firm at the business plan is positively related to the likelihood of retaining the founder as CEO, while expansion of the firm's business line is negatively related. The last regression also includes the founder ownership stake at the business plan, which is strongly positively related to retaining the founder as CEO. Although this is an endogenous variable, it can be thought of as a proxy for the bargaining power of the founder, which in turn should be correlated with the value of the founder's specific human capital. ${ }^{5}$

Our second cross-sectional analysis considers the determinants of pre-IPO founder ownership. The theories of the firm imply that founders' bargaining power should decrease in the alienability of a firm's assets. To the extent that founder ownership is a measure of bargaining power and rents, founder ownership should decrease in alienability (tangibility and patents). We present this analysis in table 14. The dependent variable is pre-IPO founder ownership. The independent variables are the asset dummies used in table 13, and the age of the firm at the business plan. Unlike the results in table 13, none of the asset dummy variables is significant in the regressions. While it may reflect a paucity of observations or that there are many other determinants of founder ownership, the results in table 14 do not provide support for the hold-up theories. The lack of a result for hold-up also suggests that the measurement issues stressed in Holmstrom (1999) may be more important than hold-up in these companies.

\section{Summary and Discussion}

In this paper, we have studied the evolution of firm characteristics from early business plan to initial public offering to public company for 49 VC financed companies. This exercise had two goals: to provide a systematic description of the early life and evolution of an important sample of firms; and to interpret our findings in relation to existing theories of the firm and what new theories might try to explain.

The typical company in our sample experiences dramatic growth. While the companies grow dramatically, their core businesses remain remarkably stable. Within core businesses, firm activities tend to

\footnotetext{
${ }^{5}$ Alternatively, it could be a proxy for the control rights that the founder retains in the venture. However, in regressions using a more direct measure of control, the fraction of founder board seats, the variable is not significant.
} 
stay the same or broaden over time. The firms also sell to similar customers and compete against similar competitors in the three stages of the life cycle we examine.

Almost uniformly, firms claim that they are differentiated by a unique product, technology or service at all three stages. The points of differentiation also tend to be stable over time. Firms stress the importance of proprietary intellectual property (IP), patents, and physical assets in all three stages. Alienable assets patents and physical assets - become increasingly important over time. At the business plan, roughly half of the firms also stress the importance of expertise (which one might interpret as human capital). The stated importance of expertise, however, declines to less than 15\% by the IPO and third annual reports.

While points of differentiation, alienable assets, customers, and competitors remain relatively constant, the human capital of the sample firms changes substantially. At the time of the annual report, onehalf of the CEOs at the business plan remain; only one-quarter of the next four top executives remain.

We believe that these results provide support for and help interpret prominent theories of the firm. Consistent with the Hart-Moore-Holmström view that a firm must be organized around non-human capital assets, non-human capital assets form very early in a firm's life. Identifiable lines of business and important physical, patent, and IP assets are created in these firms by the time of the early business plan, are relatively stable, and do not change or disappear as specific human capital assets turn over. These arguably constitute the "glue" that holds firms together.

These findings also have implications for the critical resource theories. The early emergence and stability of non-human assets are consistent with those assets being critical resources. The instability of the human assets suggests that to the extent that the initial critical resource is a specific person or founder, the "web of specific investments built around the founder(s)" itself becomes the critical resource relatively early in a firm's life.

Our cross-sectional analysis provides further support to our interpretations of the Hart-MooreHolmström and critical resource theories. Firms with more alienable assets at the time of the business plan have substantially more human capital turnover over time. Again, this suggests that specific human capital is more critical before alienable assets have formed. 
Our analysis also sheds light on the argument in Zingales (2000) and Rajan and Zingales (2001a) that today's "new firms" differ from the old, traditional firms of the (early) $20^{\text {th }}$ century in that alienable assets - assets that can be assigned or pledged to other firms - have become less important relative to human capital and non-alienable assets (for example, business processes or knowledge). This argument implies that human capital should retain a larger fraction of the value of these "new firms." The ownership results in our sample do not support this implication. Founders retain a smaller fraction of their firms at the IPO than the founders in IPOs of the 1980s studied in Baker and Gompers (1999).

From a practitioner perspective, we believe that the greater stability of lines of business and nonhuman assets in our sample relative to the stability of management teams favors the business / market / horse view of VC investing over the best available management team / jockey view except, perhaps, at the birth of a company. The results suggest that VCs are regularly able to find management replacements or improvements for good businesses. At least in our sample, we do not find cases in which VCs invest in good managers who find business replacements. An initial strong management team, therefore, is neither necessary nor sufficient. An initial strong business may not be sufficient, but appears necessary.

Some practitioners have suggested that business plans do not matter much - if a VC puts in a great management team in a mediocre business, the team will figure out what to do. Our results suggest that the business plan - whether or not it is written down - is very important.

Finally, we end with an important caveat. We have studied a special sample of firms - those VCs choose to fund. It is possible, if not likely that VCs fund companies in which specific human capital becomes less important relatively quickly. It also is possible that VCs do not allow managers to change the business. Nevertheless, our results apply to a large fraction of firms that go public - at least 39\%. A logical avenue for future research is to consider whether these results hold for non-VC backed firms. Whether or not the results generalize, however, we view the results in this paper as an early empirical look at important questions that clearly merit further research. 


\section{References}

Aghion, Philippe, and Patrick Bolton, 1992, An incomplete contracts approach to financial contracting, Review of Economic Studies, 77: 338-401.

Aghion, Philippe, Mathias Dewatripont, and Jeremy Stein, 2005, Academic Freedom, Private-Sector Focus, and the Process of Innovation, working paper, Harvard University.

Baker, Malcom, and Paul Gompers, 1999, Executive Ownership and Control in Newly Public Firms: The Role of Venture Capitalists, working paper, Harvard Business School.

Baron, James N., Michael T. Hannan, 2002, Organizational Blueprints for Success in High-Tech Start-Ups: Lessons from the Stanford Project on Emerging Companies, California Management Review, Vol. 44, No. 3 (Spring).

Baron, James N., Michael T. Hannan, and M. Diane Burton. 1999. Building the Iron Cage: Determinants of Managerial Intensity in the Early Years of Organizations. American Sociological Review 64:527-47.

—. 2001. Labor Pains: Organizational Change and Employee Turnover in Young, High-Tech Firms” American Journal of Sociology 105.

Bertrand, Marianne and Antoinette Schoar, 2003. Managing with Style: The Effect of Managers on Firm Policies, Quarterly Journal of Economics 118, 1169-1208.

Bhide, Amar, 2000, The Origin and the Evolution of New Businesses (New York, NY: Oxford University Press).

Chandler, Alfred, 1977, The Visible Hand (Cambridge, MA: Belknap Press).

Chandler, Alfred, 1990, Scale and Scope (Cambridge, MA: Belknap Press).

Coase, Ronald, 1937, The Nature of the Firm, Economica 4, 386-405.

Fama, Eugene, and Kenneth French, 2003, New Lists: Fundamentals and Survival Rates, working paper, University of Chicago.

Franks, Julian, Colin Mayer, and Stefano Rossi, 2005, Ownership: Evolution and Regulation, Working paper, London Business School.

Gibbons, Robert, forthcoming, Four Formal(izable) Theories of the Firm? Journal of Economic Behavior and Organization.

Gompers, Paul and Josh Lerner, 1999, The Venture Capital Cycle (Cambridge, MA: MIT Press).

Gompers, Paul, Josh Lerner, and David Scharfstein, 2005, Entrepreneurial Spawning: Public Corporations and the Genesis of New Ventures, 1986 to 1999, Journal of Finance.

Hannan, Michael, James N. Baron, Greta Hsu, and Ozgecan Kocak. 2000. Staying the Course: Early Organization Building and the Success of High-Technology Firms, Working paper, Stanford University.

Hart, Oliver, 1995, Firms, Contacts, and Financial Structure (Oxford: Clarendon Press.)

Hart, Oliver, and John Moore, 1994, A Theory of Debt Based on the Inalienability of Human Capital, Quarterly Journal of Economics 109, 841-879.

Hellman, Thomas and Manju Puri, 2000, The interaction between product market and financial strategy: The role of venture capital, Review of Financial Studies 13, 959-984. 
Hellman, Thomas and Manju Puri, 2002, Venture capital and the professionalization of start-up firms: Empirical evidence, Journal of Finance.

Holmström, Bengt, 1999, “The Firm as a Subeconomy,” Journal of Law, Economics, and Organization 15, 74-102.

Holmström, Bengt and John Roberts, 1998, “Boundaries of the firm revisited,” Journal of Economic Perspectives 12 73-94.

Jensen, Michael and William Meckling, 1976, The Theory of the Firm: Managerial Behavior, Agency Costs, And Ownership Structure, Journal of Financial Economics, III, 305-360.

Kaplan, Steven and Per Strömberg. 2003, Financial Contracting Theory Meets the Real World: An Empirical Analysis of Venture Capital Contracts, Review of Economic Studies 70, 281-316.

Kaplan, Steven and Per Strömberg, 2004, Characteristics, Contracts, and Actions: Evidence From Venture Capitalist Analyses, Journal of Finance 59, 2177-2210

Milgrom, Paul and Michael Roberts, 1992, Economics, Organization and Management.

Quindlen, Ruthann, 2000, Confessions of a Venture Capitalist (New York, NY: Warner Books).

Rajan, Raghuram, and Zingales, Luigi, 1998, Power in a theory of the firm, Quarterly Journal of Economics 108, 387-432.

Rajan, Raghuram, and Zingales, Luigi 2001a, The Influence of the Financial Revolution on the Nature of Firms, American Economic Review 91, 206-212.

Rajan, Raghuram, and Zingales, Luigi. 2001b, The firm as a dedicated hierarchy: A theory of the origins and growth of firms, Quarterly Journal of Economics, 805-850.

Sahlman, William, 1990, The Structure and Governance of Venture Capital Organizations, Journal of Financial Economics 27, 473-521.

Santos, Filipe and Kathleen Eisenhardt, 2004, Constructing Markets and Organizing Boundaries: Entrepreneurial Action in Nascent Fields, working paper, Insead.

Wernerfelt, Birger, 1984, A Resource Based View of the Firm, Strategic Management Journal 5, 171-180.

Zingales, Luigi, 2000, In Search of New Foundations, Journal of Finance 55, 1623- 1653. 
Table 1 - Sample Summary

Median, average, and standard deviation of (i) the age of the firm in months as of the date of the business plan (BP), (ii) the time elapsed in months between the business plan and the IPO, (iii) the time elapsed in months between the IPO and the annual report (AR), and (iv) the time elapsed in months between business plan and the annual report for $49 \mathrm{VC}$-financed companies that subsequently went public. The table also reports frequency distributions of the number of founders, the dates sample firms were founded, the dates of their business plans, IPOs, and annual reports, the industries in which they operate, and their status as of August 2004.

\begin{tabular}{|c|c|c|c|}
\hline & Months between & Months between & Months between \\
\hline $\begin{array}{l}\text { Age (months) at } \\
\text { Business Plan }\end{array}$ & $\begin{array}{l}\text { Business Plan } \\
\text { and IPO }\end{array}$ & $\begin{array}{l}\text { IPO and } \\
\text { Annual Report }\end{array}$ & $\begin{array}{l}\text { Business Plan } \\
\text { and Annual Repor }\end{array}$ \\
\hline
\end{tabular}

$\begin{array}{lllll}\text { Median } & 24 & 34 & 33 & 63 \\ \text { Average } & 40 & 38 & 32 & 68 \\ \text { St. dev. } & 51 & 23 & 8 & 23 \\ \text { Num. Obs. } & 49 & 49 & 39 & 39\end{array}$

Number of companies with Business Plan dated prior to or concurrent with first VC financing: 19

Number of companies with one founder: $\quad 21$

Number of companies with two co-founders: $\quad 16$

Number of companies with three or more co-founders: 11

\begin{tabular}{|c|c|c|c|c|}
\hline & $\begin{array}{l}\text { Number firms } \\
\text { founded }\end{array}$ & $\underline{\text { Number BPs }}$ & $\underline{\text { Number IPOs }}$ & Number ARs \\
\hline $1975-1980$ & $\overline{3}$ & & & \\
\hline 1980-1984 & 2 & & & \\
\hline 1985-1989 & 5 & 4 & 1 & \\
\hline 1990 & 1 & 1 & & \\
\hline 1991 & 4 & & & 1 \\
\hline 1992 & 3 & & 2 & \\
\hline 1993 & 2 & 3 & & \\
\hline 1994 & 7 & 1 & & 1 \\
\hline 1995 & 9 & 8 & 3 & 1 \\
\hline 1996 & 5 & 11 & 3 & \\
\hline 1997 & 2 & 9 & 3 & 2 \\
\hline 1998 & 6 & 9 & 5 & 3 \\
\hline 1999 & & 2 & 14 & 1 \\
\hline 2000 & & & 12 & 9 \\
\hline 2001 & & 1 & & 5 \\
\hline 2002 & & & 1 & 9 \\
\hline 2003 & & & 1 & 6 \\
\hline 2004 & & & 4 & 1 \\
\hline
\end{tabular}

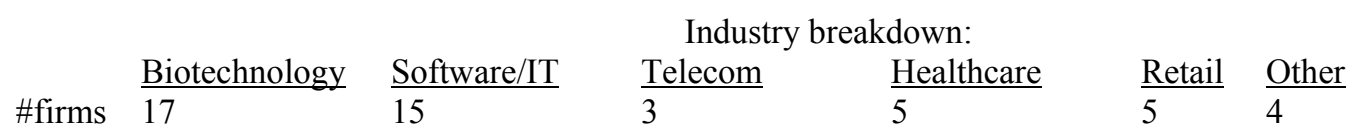

Status as of $7 / 31 / 2005$ :

\#firms $\quad \frac{\text { Active }}{27} \quad \frac{\text { Acquired / Merged }}{15} \quad \frac{\text { Bankrupt }}{7}$ 
Table 2

Financials and Employees

Median, average, and standard deviation of revenue, assets, earnings before interest and taxes (EBIT), net income, market capitalization, EBIT to revenue ratio, market capitalization to book assets ratio, number of employees, and revenue per employee at the business plan (BP), IPO, and annual report (AR) for $49 \mathrm{VC}$

financed companies that subsequently went public. Revenue, net income, and assets are reported as of the end of the prior fiscal year. Panel A reports statistics broken out by all sample firms, biotechnology firms, and non-biotechnology firms. Panel B reports some statistics for non-retail firms.

$\underline{\text { Panel A }}$

\begin{tabular}{|c|c|c|c|c|c|c|c|c|c|}
\hline \multirow{3}{*}{ Revenue (\$M) } & \multicolumn{3}{|l|}{$\underline{\text { All firms }}$} & \multicolumn{3}{|c|}{$\underline{\text { Biotechnology firms }}$} & \multirow{2}{*}{\multicolumn{3}{|c|}{$\underline{\text { Non-biotechnology firms }}$}} \\
\hline & & & & & & & & & \\
\hline & $\underline{\mathrm{BP}}$ & $\underline{\mathrm{IPO}}$ & $\underline{\mathrm{AR}}$ & $\underline{\mathrm{BP}}$ & $\underline{\mathrm{IPO}}$ & $\underline{\mathrm{AR}}$ & $\underline{\mathrm{BP}}$ & $\underline{\mathrm{IPO}}$ & $\underline{\mathrm{AR}}$ \\
\hline Median & 0 & $\overline{7.2}$ & $\overline{35.1}$ & 0 & $\overline{2.9}$ & $\overline{20.7}$ & $\overline{0.6}$ & $\overline{12.7}$ & $\overline{97.5}$ \\
\hline Average & 5.54 & 40.5 & 179.0 & 0.7 & 4.9 & 30.1 & 8.3 & 59.5 & 241.4 \\
\hline St. dev. & 13.6 & 154.5 & 332.7 & 1.6 & 5.3 & 14.8 & 16.5 & 189.4 & 376.0 \\
\hline Num. Obs. & 47 & 49 & 39 & 17 & 17 & 11 & 30 & 32 & 28 \\
\hline \multicolumn{10}{|c|}{ Revenue percentage change } \\
\hline Median & 390 & 408 & 2,591 & 140 & 419 & 209 & 607 & 397 & 2,094 \\
\hline Average & 2,954 & $3,569,242$ & 63,255 & 131 & 18,249 & 821 & 3,378 & $5,131,678$ & 74,273 \\
\hline St. dev. & 7,593 & $21,400,000$ & 234,524 & 224 & 56,443 & 1,229 & 8,081 & $25,700,000$ & 253,878 \\
\hline Num. Obs. & 23 & 36 & 20 & 3 & 11 & 3 & 20 & 25 & 17 \\
\hline \multicolumn{10}{|c|}{ Number of employees } \\
\hline & $\underline{\mathrm{BP}}$ & $\underline{\mathrm{IPO}}$ & $\underline{\mathrm{AR}}$ & $\underline{\mathrm{BP}}$ & $\underline{\mathrm{IPO}}$ & $\underline{\mathrm{AR}}$ & $\underline{\mathrm{BP}}$ & $\underline{\mathrm{IPO}}$ & $\underline{\mathrm{AR}}$ \\
\hline Median & $\overline{22}$ & $\overline{124}$ & 378 & $\overline{10}$ & 71 & $\overline{134}$ & $\overline{31}$ & $\overline{209}$ & $\overline{561}$ \\
\hline St. dev. & 202 & 659 & 2,320 & 13 & 67 & 141 & 246 & 785 & 2,630 \\
\hline Num. Obs. & 42 & 49 & 39 & 16 & 17 & 11 & 26 & 32 & 28 \\
\hline \multicolumn{10}{|c|}{ Number of employees percentage change } \\
\hline & BP to IPO & IPO to AR & $\underline{\mathrm{BP}}$ to $\mathrm{AR}$ & $\underline{\mathrm{BP}}$ to IPO & IPO to AR & $\underline{\mathrm{BP}}$ to $\mathrm{AR}$ & $\underline{\mathrm{BP}}$ to IPO & $\underline{\mathrm{IPO}}$ to $\mathrm{AR}$ & $\underline{\mathrm{BP}}$ to $\mathrm{AR}$ \\
\hline Median & 515 & 100 & 1,519 & 528 & 62 & 1,170 & 500 & 125 & 2,023 \\
\hline Average & 720 & 277 & 3,848 & 579 & 128 & 1,803 & 806 & 336 & 4,700 \\
\hline St. dev. & 808 & 492 & 7,617 & 544 & 183 & 1,970 & 935 & 562 & 8,896 \\
\hline Num. Obs. & 42 & 39 & 34 & 16 & 11 & 10 & 26 & 28 & 24 \\
\hline
\end{tabular}


All firms

Revenue per employee (\$thousand)

$\begin{array}{llll} & \underline{\mathrm{BP}} & \underline{\mathrm{IPO}} & \underline{\mathrm{AR}} \\ \text { Median } & 0 & 50.5 & 124.6 \\ \text { Average } & 29.5 & 63.3 & 139.4 \\ \text { St. dev. } & 58.5 & 64.5 & 98.7 \\ \text { Num. Obs. } & 42 & 49 & 39\end{array}$

Revenue per employee percentage change

\begin{tabular}{|c|c|c|c|}
\hline & BP to IPO & IPO to AR & $\mathrm{BP}$ to $\mathrm{AR}$ \\
\hline Median & 51 & 116 & 374 \\
\hline Average & 269 & 217,486 & 1497 \\
\hline St. dev. & 518 & $1,290,494$ & 3815 \\
\hline Num. Obs. & 18 & 36 & 16 \\
\hline
\end{tabular}

Assets (\$M)

\begin{tabular}{|c|c|c|c|}
\hline & $\underline{\mathrm{BP}}$ & $\underline{\mathrm{IPO}}$ & $\underline{\mathrm{AR}}$ \\
\hline Median & 2.6 & 19.6 & 96.7 \\
\hline Average & 5.9 & 44.3 & 274.9 \\
\hline St. dev. & 10.8 & 69.6 & 663.0 \\
\hline Num. Obs. & 35 & 49 & 39 \\
\hline
\end{tabular}

Assets percentage change

\begin{tabular}{|c|c|c|c|}
\hline & BP to IPO & IPO to AR & BP to AR \\
\hline Median & 430 & 287 & 2,498 \\
\hline Average & 2,570 & 913 & 52,605 \\
\hline St. dev. & 6,137 & 1,812 & 158,013 \\
\hline Num. Obs. & 30 & 39 & 24 \\
\hline
\end{tabular}

\section{$\underline{\operatorname{EBIT}(\$ M)}$}

\begin{tabular}{llll}
\hline & $\underline{\mathrm{BP}}$ & $\underline{\mathrm{IPO}}$ & $\underline{\mathrm{AR}}$ \\
Median & -0.8 & -6.7 & -25.6 \\
Average & -1.6 & -7.7 & -48.6 \\
St. dev. & 2.5 & 13.5 & 93.3 \\
Num. Obs. & 36 & 49 & 39 \\
\% positive & $17 \%$ & $18 \%$ & $15 \%$
\end{tabular}

Table 2 (continued)

Biotechnology firms

$\begin{array}{lll}\underline{\text { BP }} & \underline{\text { IPO }} & \underline{\text { AR }} \\ 0 & 48.9 & 87.7 \\ 5.8 & 45.9 & 97.7 \\ 16.4 & 40.0 & 66.9 \\ 16 & 17 & 11\end{array}$

\begin{tabular}{|c|c|c|}
\hline BP to IPO & IPO to AR & $\underline{\mathrm{BP}}$ to $\mathrm{AR}$ \\
\hline-17 & 111 & 163 \\
\hline-17 & 6,685 & 163 \\
\hline 113 & 20,714 & 237 \\
\hline 2 & 11 & 2 \\
\hline
\end{tabular}

$\begin{array}{lll}\underline{\text { BP }} & \underline{\text { IPO }} & \underline{\text { AR }} \\ 1.8 & 18.5 & 91.7 \\ 3.3 & 23.7 & 96.7 \\ 3.9 & 18.3 & 64.5 \\ 9 & 17 & 11\end{array}$

\begin{tabular}{|c|c|c|}
\hline BP to IPO & IPO to AR & $\underline{\mathrm{BP}}$ to $\mathrm{AR}$ \\
\hline 689 & 361 & 1,077 \\
\hline 1,231 & 646 & 3,505 \\
\hline 1,557 & 994 & 5,877 \\
\hline 8 & 11 & 5 \\
\hline
\end{tabular}

$\begin{array}{lll}\frac{\mathrm{BP}}{-1.4} & \underline{\mathrm{IPO}} & \underline{\mathrm{AR}} \\ -1.9 & -10.3 & -32.8 \\ 2.0 & -11.7 & -30.4 \\ 8 & 7.5 & 18.1 \\ 13 \% & 17 & 11 \\ & 6 \% & 0 \%\end{array}$

Non-biotechnology firms

$\begin{array}{lll}\frac{\mathrm{BP}}{9.9} & \underline{\mathrm{IPO}} & \underline{\mathrm{AR}} \\ 44.0 & 72.5 & 136.3 \\ 69.8 & 73.3 & 155.8 \\ 26 & 32 & 105.2\end{array}$

\begin{tabular}{|c|c|c|}
\hline BP to IPO & $\underline{\text { IPO to AR }}$ & $\underline{\mathrm{BP}}$ to $\mathrm{AR}$ \\
\hline 63 & 120 & 453 \\
\hline 304 & 310,239 & 1,687 \\
\hline 539 & $1,548,924$ & 4,059 \\
\hline 16 & 25 & 14 \\
\hline
\end{tabular}

$\begin{array}{lll}\frac{\mathrm{BP}}{2.9} & \underline{\mathrm{IPO}} & \underline{\mathrm{AR}} \\ 6.7 & 20.8 & 108.9 \\ 12.3 & 55.4 & 345.0 \\ 26 & 83.5 & 773.9 \\ & 32 & 28\end{array}$

\begin{tabular}{|c|c|c|}
\hline BP to IPO & IPO to AR & BP to AR \\
\hline 396 & 274 & 3,253 \\
\hline 3,057 & 1,018 & 65,526 \\
\hline 7,090 & 2,053 & 176,211 \\
\hline 22 & 28 & 19 \\
\hline
\end{tabular}

$\begin{array}{lll}\underline{\mathrm{BP}} & \underline{\mathrm{IPO}} & \underline{\mathrm{AR}} \\ -0.8 & -5.4 & -22.4 \\ -1.5 & -5.6 & -55.8 \\ 2.6 & 15.5 & 109.2 \\ 26 & 32 & 28 \\ 18 \% & 25 \% & 21 \%\end{array}$


EBIT percentage change

\begin{tabular}{|c|c|c|c|}
\hline & BP to IPO & IPO to AR & $\underline{\mathrm{BP}}$ to $\mathrm{AR}$ \\
\hline Median & 159 & 156 & 996 \\
\hline Average & 1,149 & $-2,129$ & 9,818 \\
\hline St. dev. & 2,978 & 15,320 & 43,675 \\
\hline Num. Obs. & 32 & 39 & 28 \\
\hline
\end{tabular}

Market capitalization (\$M)

\begin{tabular}{|c|c|c|c|}
\hline & $\mathrm{BP}$ & IPO & AR \\
\hline Median & $\overline{17.9}$ & $\overline{232.4}$ & $\overline{176.9}$ \\
\hline Average & 29.0 & 697.7 & 470.8 \\
\hline St. dev. & 32.9 & 1920.3 & 1378.6 \\
\hline Num. Obs. & 40 & 49 & 38 \\
\hline
\end{tabular}

Market capitalization percentage change

\begin{tabular}{|c|c|c|c|}
\hline & $\underline{\mathrm{BP}}$ to IPO & IPO to AR & $\mathrm{BP}$ to $\mathrm{AR}$ \\
\hline Median & 1,586 & -55 & 496 \\
\hline Average & 7,778 & 98 & 10,492 \\
\hline St. dev. & 108865 & 362 & 37,055 \\
\hline Num. Obs. & 40 & 38 & 34 \\
\hline
\end{tabular}

Num. Obs.
Table 2 (continued)

Market capitalization to assets ratio

\begin{tabular}{llll}
\hline Median & $\underline{\mathrm{BP}}$ & $\underline{\mathrm{IPO}}$ & \\
Average & 5.4 & 13.9 & \\
St. dev. & 8.9 & 23.6 & 2.3 \\
Num. Obs. & 10.1 & 25.2 & 2.1 \\
. & 25 & 49 & 38
\end{tabular}

Market capitalization to assets ratio percentage change

\begin{tabular}{|c|c|c|c|}
\hline & BP to IPO & IPO to AR & BP to AR \\
\hline Median & 80 & -89 & -61 \\
\hline Average & 328 & -65 & -23 \\
\hline St. dev. & 588 & 73 & 162 \\
\hline Num. Obs. & 25 & 38 & 21 \\
\hline
\end{tabular}

\begin{tabular}{|c|c|c|}
\hline$\underline{\mathrm{BP}}$ to IPO & IPO to AR & $\underline{\mathrm{BP}}$ to AR \\
\hline 538 & 239 & 755 \\
\hline 969 & 182 & 2,938 \\
\hline 1,554 & 212 & 6,157 \\
\hline 7 & 11 & 6 \\
\hline
\end{tabular}

$\begin{array}{lll}\frac{\mathrm{BP}}{14.1} & \underline{\mathrm{IPO}} & \underline{\mathrm{AR}} \\ 16.2 & 384.9 & 265.8 \\ 11.9 & 368.2 & 257.6 \\ 10 & 17 & 216.2\end{array}$

\begin{tabular}{|c|c|c|}
\hline$\underline{\mathrm{BP}}$ to IPO & $\underline{\text { IPO to AR }}$ & $\underline{\mathrm{BP}}$ to $\mathrm{AR}$ \\
\hline 2,064 & -53 & 2,370 \\
\hline 7,101 & 14 & 2,830 \\
\hline 16,631 & 139 & 3,146 \\
\hline 10 & 11 & 9 \\
\hline
\end{tabular}

\begin{tabular}{|c|c|c|}
\hline$\underline{\mathrm{BP}}$ to IPO & $\underline{\mathrm{IPO} \text { to } \mathrm{AR}}$ & $\underline{\mathrm{BP}}$ to $\mathrm{AR}$ \\
\hline 120 & 154 & 1,046 \\
\hline 1,199 & $-3,037$ & 11,694 \\
\hline 3,292 & 18,091 & 49,258 \\
\hline 25 & 28 & 22 \\
\hline
\end{tabular}

$\begin{array}{lll}\frac{\mathrm{BP}}{18.7} & \underline{\mathrm{IPO}} & \underline{\mathrm{AR}} \\ 33.3 & 862.8 & 163.5 \\ 36.5 & 2357.8 & 557.7 \\ 30 & 32 & 1630.9\end{array}$

\begin{tabular}{|c|c|c|}
\hline$\underline{\mathrm{BP}}$ to IPO & $\underline{\text { IPO to AR }}$ & $\underline{\mathrm{BP}}$ to $\mathrm{AR}$ \\
\hline 1,409 & -57 & 417 \\
\hline 8,005 & 132 & 13,250 \\
\hline 19,813 & 418 & 43,066 \\
\hline 30 & 27 & 25 \\
\hline
\end{tabular}

$\begin{array}{lll}\frac{\mathrm{BP}}{2.3} & \underline{\mathrm{IPO}} & \underline{\mathrm{AR}} \\ 5.1 & 13.6 & 2.2 \\ 5.6 & 22.1 & 2.8 \\ 5 & 21.1 & 2.5 \\ & 17 & 11\end{array}$

$\begin{array}{lll}\frac{\mathrm{BP}}{7.1} & \underline{\mathrm{IPO}} & \underline{\mathrm{AR}} \\ 9.9 & 15.6 & 1.6 \\ 10.8 & 24.5 & 2.0 \\ 20 & 27.4 & 1.9 \\ & 32 & 27\end{array}$

\begin{tabular}{|c|c|c|}
\hline$\underline{\mathrm{BP}}$ to IPO & IPO to AR & $\underline{\mathrm{BP}}$ to $\mathrm{AR}$ \\
\hline 110 & -91 & -38 \\
\hline 694 & -79 & 120 \\
\hline 1015 & 25 & 354 \\
\hline 5 & 11 & 4 \\
\hline
\end{tabular}

\begin{tabular}{|c|c|c|}
\hline$\underline{\mathrm{BP}}$ to IPO & IPO to AR & $\underline{\mathrm{BP}}$ to $\mathrm{AR}$ \\
\hline 62 & -89 & -74 \\
\hline 237 & -60 & -57 \\
\hline 420 & 85 & 52 \\
\hline 20 & 27 & 17 \\
\hline
\end{tabular}


Table 2 (continued)

Panel B - Excluding retail firms

Percentage Change

$\underline{B P} \underline{I P O} \quad \underline{A R} \quad \underline{\text { BP to IPO }} \underline{\text { IPO to AR }} \quad \underline{B P}$ to AR

Number of employees

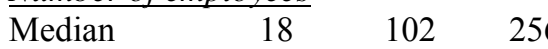

Average $\quad 56 \quad 179 \quad 582$

$\begin{array}{llll}\text { St. dev. } & 115 & 216 & 991\end{array}$

Num. Obs.

38

$44 \quad 34$

523

726

821

38

96
258

1,519

3,958

8,056

30

Revenue per employee (\$thousand)

$\begin{array}{llll}\text { Median } & 0 & 43.6 & 121.7\end{array}$

$\begin{array}{llll}\text { Average } & 23.2 & 55.3 & 135.0\end{array}$

51

309

580

St. dev.

$\begin{array}{lll}54.3 & 53.8 & 96.5\end{array}$

Num. Obs.

38

$44 \quad 34$

14

493

34

$\begin{array}{ll}164 & 409 \\ 252,558 & 1,908 \\ 1,390,606 & 4,369 \\ 31 & 12\end{array}$


Table 3

Lines of Business

Stated business at the business plan, IPO, and annual report, as well as the percentage of companies whose stated lines of business broaden, narrow, or stay the same over those periods for $49 \mathrm{VC}$ financed companies that subsequently went public. Panel B categorizes the origin of each company's business idea, according to the business plan, as an existing business, academic research, a previous employer of the founder(s), or unknown. Panel B also categorizes business strategies as of the business plan according to the Baron, Hannan, and Burton (1999) classification system.

\section{Panel A}

\begin{tabular}{|c|c|c|c|}
\hline \multirow[b]{2}{*}{ Company } & \multicolumn{3}{|c|}{ Companies whose line of business stays about the same over time } \\
\hline & $\underline{\text { Business Plan }}$ & $\underline{\text { IPO }}$ & Annual Report \\
\hline 1 & -Development of analgesics & -Development of analgesics & -Development of analgesics \\
\hline 2 & $\begin{array}{l}\text {-Chemical analysis instrumentation } \\
\text { and research services }\end{array}$ & $\begin{array}{l}\text { - Contract research and development } \\
\text { services }\end{array}$ & $\begin{array}{l}\text {-Contract research and development } \\
\text { services }\end{array}$ \\
\hline 3 & -Specialty supermarkets & - Specialty supermarkets & - Specialty supermarkets \\
\hline 4 & $\begin{array}{l}\text {-Customer information } \\
\text { management software }\end{array}$ & $\begin{array}{l}\bullet \text { Enterprise relationship } \\
\text { management software }\end{array}$ & $\begin{array}{l}\text {-Enterprise customer relationship } \\
\text { management software }\end{array}$ \\
\hline 5 & -Category-dominant specialty retailer & -Specialty retailer & - Specialty retailer \\
\hline 6 & -Sustained-release drug delivery systems & -Sustained-release drug delivery systems & -Sustained-release drug delivery systems \\
\hline 7 & $\bullet$ Non-invasive cardiac surgery & $\bullet$ Non-invasive cardiac surgery & -Non-invasive cardiac surgery \\
\hline 8 & -Production of nanocrystalline materials & $\begin{array}{l}\text {-Development and marketing of } \\
\text { nanocrystalline materials }\end{array}$ & $\begin{array}{l}\text {-Engineering and manufacturing of } \\
\text { nanocrystalline materials }\end{array}$ \\
\hline 9 & -Telecom service provider & -Telecom service provider & -Telecom service provider \\
\hline 10 & - Superstore specialty retailer & - Full-line specialty retailer & - Full-line specialty retailer \\
\hline 11 & $\bullet$ Office supply stores & -Office supply stores & - Office supply stores \\
\hline 12 & $\bullet$ Digital prepress equipment & $\bullet$ Digital prepress equipment & \\
\hline 13 & $\begin{array}{l}\text { - Maps and mapping-related } \\
\text { products, services, and technology }\end{array}$ & -Mapping products and services & \\
\hline 14 & $\begin{array}{l}\text { - Therapeutic products for cancer and } \\
\text { infectious diseases }\end{array}$ & $\begin{array}{l}\text { - Therapeutic products for cancer and } \\
\text { infectious diseases }\end{array}$ & \\
\hline 15 & - Small business equipment leasing & - Small business equipment leasing & \\
\hline
\end{tabular}




\section{Table 3 (cont.)}

Companies whose line of business broadens/narrows (B/N) between the business plan and IPO but not between the IPO and the annual report

\section{Company $\quad$ Business Plan}

-Wireless data communications
-Web-based enterprise application software

-Experimentation platform for a wide range of biological analyses

- Combinatorial chemistry

- Software and services to industries

transformed by human genome research

- Implantable hearing devices

-Drug screening and discovery

-Drug target discovery

-Products for the treatment of abnormal uterine bleeding

-Products and services to accelerate drug discovery

-Internet-based micropayments system and incentive currency

-Treatment for psychotic major depression

-Discovery and development of drugs for memory-related disorders

-Development of treatments for pulmonary inflammatory diseases

\section{$\underline{\mathrm{IPO}}$}

(N) Wireless communication and

information systems for health information

(N) Live business collaboration software and services

(N) Tools for large-scale analysis of genetic variation and function

(N) Computational drug discovery

(N) Software products and services to accelerate drug

discovery and development

(B) Implantable and semi-implantable hearing devices

(B) Drug candidate development

(B) Drug target discovery and small

molecule drug development

(B) Surgical systems for the diagnosis and

treatment of gynecological disorders

(B) Creating drug candidates through innovations in chemistry

(B) Internet-based direct marketing and advertising services combined with programs that reward consumers with cash

(B) Drug development for severe psychiatric and neurological diseases

(B) Development of drugs for a broad range of centra nervous system disorders

(B) Discovery and development of treatments for allergies, infectious diseases, and chronic inflammatory diseases

\section{Annual Report}

-Wireless health information

communication systems

-Application software and services for realtime enterprise collaboration

-Tools for large-scale analysis of genetic

variation and function

-Implantable and semi-implantable hearing devices

-Drug candidate development

- Small molecule drug discovery and

development

- Surgical systems for the diagnosis and

treatment of gynecological disorders

- Creating small molecule drugs through the integration of chemistry, biology and informatics 


\section{Table 3 (cont.)}

\section{Companies whose line of business broadens/narrows (B/N) between IPO and annual report but not between business plan and IPO}

\section{Business Plan}

30

and cardiovascular disease

-Internet data delivery software

-Sales and marketing automation software

•Microfluidics

-Upscale, casual ethnic restaurants

\section{$\underline{\mathrm{IPO}}$}

-Diagostic imaging and treatment of cancer,

artherosclerosis, and other diseases

- Internet data delivery software

-Sales, marketing, and customer support

automation software

-Microfluidics

-Upscale, casual ethnic restaurants

\section{Annual Report}

(N) New drugs to treat cancer and artheroscelerosis

(B) E-business infrastructure software and services

(B) Customer relationship management software

(B) Novel assay chemistry solutions for drug discovery and development

(B) Upscale, casual ethnic restaurants and casual ethnic diners

\section{Companies whose line of business broadens/narrows $(B / N)$ between both the business plan and IPO and the IPO and annual report}

\section{Business Plan \\ $\underline{\mathrm{PO}}$}

-E-commerce solutions

-Disease prevention

- Novel antimicrobial compounds

Internet marketing software

- Internet communication services

-Website production software

-Hotel reservation and

commission collection system

- Market research

- Semiconductor laser diodes and related

systems and subsystems

-Local switched telecommunications services

- Basic local telephone services

- Customer interaction software

-Sterilization systems for medical instruments
E-commerce and direct marketing services

(N) Live-virus vaccines

(B) New antibacterial and antifungal drugs

(B) Internet marketing and data aggregation software

(B) Internet system and network management

(B) Web content management software

(B) Transaction processing services for the worldwide hotel industry

(B) Market research and polling

(B) Semiconductor optoelectronic integrated circuits and high power semiconductor lasers

(B) Competitive local exchange carrier

(B) Facilities-based competitive local exchange carrie

(B) E-business infrastructure software

(B) Sterile processing and infection prevention systems

(B) Gene and drug target discovery, database, and information technology products and services

\section{Annual Report}

(B) Technology infrastructure and services

(B) Disease prevention through vaccine technology

(N) Prevention of ventilator-associated pneumonia

(B) E-business products and services

(B) Internet infrastructure outsourcing

(B) Enterprise content management software

(B) Hotel reservation and representation services for the global hotel industry

(B) Market research and consulting

(B) Semiconductor circuits and lasers; fiberoptic systems

(B) National communications provider

(B) Facilities-based operator of a fiber optic communications infrastructure

(B) Enterprise software vendor

(B) Infection prevention, contamination control, microbial reduction, and critical care support products and services

(B) Population genetics company developing drugs and DNA-based diagnostics

Companies whose line of business changes $(C)$ between both the business plan and IPO and the IPO and annual report

\section{Business Plan}

-New computing platform
IPO

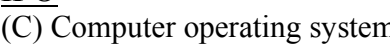

Annual Report

(C) Software solutions for Internet appliances 
Table 3 (cont.)

All Firms

Percent whose business model changes

Number observations

\section{All Firms}

Percent whose line of business

Stays about the same

Broadens

Narrows

Number observations

\section{Biotechnology Firms}

Percent whose line of business

Stays about the same

Broadens

Narrows

Number observations

Non-biotechnology Firms

Percent whose line of business

Stays about the same

Broadens

Narrows

Number observations

$\frac{\mathrm{BP} \text { to IPO }}{2}$

49
$\underline{\mathrm{IPO} \text { to } \mathrm{AR}}$
3

39

\begin{tabular}{|c|c|}
\hline $\mathrm{BP}$ to IPO & IPO to $\mathrm{AR}$ \\
\hline 42 & 42 \\
\hline 46 & 50 \\
\hline 13 & 8 \\
\hline
\end{tabular}

48

BP to IPO

29

47

24

17

\begin{tabular}{c} 
IPO to AR \\
\hline 55 \\
27
\end{tabular}

18

11

\begin{tabular}{r} 
BP to IPO \\
\hline 49 \\
45 \\
6
\end{tabular}

\begin{tabular}{c} 
IPO to AR \\
\hline 37 \\
59 \\
4
\end{tabular}

$31 \quad 27$
$\underline{\mathrm{BP} / \mathrm{IM} \text { to } \mathrm{AR}}$

45

52

3

$\frac{\mathrm{BP} / \mathrm{IM} \text { to } \mathrm{AR}}{3}$

39

37

50

13

38

27

\section{Panel B}

Origin of Business Idea:

$\begin{array}{lllll} & \begin{array}{l}\text { Existing } \\ \text { business }\end{array} & \begin{array}{l}\text { Previous } \\ \text { employer }\end{array} & \begin{array}{l}\text { Academic } \\ \text { research }\end{array} & \begin{array}{l}\text { Out of the blue } \\ \text { or unknown }\end{array} \\ \text { All firms } & 5 & 15 & 14 & 15 \\ \text { Biotech } & 1 & 2 & 10 & 4 \\ \text { Non-Biotech } & 4 & 13 & 4 & 11\end{array}$

Baron et al. (1999) classification of business plan strategy:

\begin{tabular}{|c|c|c|c|c|}
\hline & Innovator & Enhancer & Marketing & Tech/marketing hybrid \\
\hline All firms & 24 & 11 & 5 & 6 \\
\hline Biotech & 12 & 4 & 0 & 1 \\
\hline Non-Biotech & 12 & 7 & 5 & 5 \\
\hline
\end{tabular}


Table 4

\section{Point of differentiation}

Percent of companies that explicitly mention the following characteristics as those that distinguish the company: unique product, service, or technology; comprehensive product offerings; strong customer service; alliances, partnerships, and other business relationships; management and/or employee expertise; strength of scientific advisors; and reputation for $49 \mathrm{VC}$-financed companies that subsequently went public. We also report the percentages of companies who do or do not change what they consider their distinguishing characteristics over time (e.g. The "yes to no" column under "BP to IPO" reflects the percentage of companies who report a given item as a distinguishing characteristic in the business plan but not at the IPO).

Unique product/technology

Comprehensive products

Customer service

Alliances/partnerships

Expertise

Scientific advisors

Reputation

Number of observations

Unique product/technology

Comprehensive products

Customer service

Alliances/partnerships

Expertise

Scientific advisors

Reputation

Number of observations

\begin{tabular}{|c|c|c|}
\hline BP & IPO & \\
\hline \multicolumn{3}{|c|}{ All firms } \\
\hline 100 & 98 & \\
\hline 6 & 12 & \\
\hline 8 & 16 & \\
\hline 12 & 12 & \\
\hline 45 & 14 & \\
\hline 4 & 2 & \\
\hline 6 & 8 & \\
\hline 49 & 49 & \\
\hline
\end{tabular}

$\underline{\text { BP to IPO }}$

$\begin{array}{llll}\text { Yes } & \text { Yes } & \text { No } & \text { No } \\ \text { to } & \text { to } & \text { to } & \text { to } \\ \text { yes } & \text { no } & \text { yes } & \text { no }\end{array}$

$\begin{array}{llll}98 & 2 & 0 & 0\end{array}$

$\begin{array}{llll}4 & 2 & 8 & 86\end{array}$

$\begin{array}{llll}8 & 0 & 8 & 84\end{array}$

$\begin{array}{llll}8 & 37 & 6 & 49\end{array}$

$\begin{array}{llll}2 & 2 & 0 & 96\end{array}$

49

$\begin{array}{lll}\frac{\mathrm{BP}}{\text { Biotechnology }} & \underline{\mathrm{IPO}} & \underline{\mathrm{AR}} \\ 100 & 100 & 91 \\ 6 & 6 & 0 \\ 0 & 6 & 9 \\ 0 & 12 & 0 \\ 47 & 12 & 18 \\ 6 & 0 & 0 \\ 0 & 6 & 9 \\ 17 & 17 & 11\end{array}$

\section{$\underline{\text { IPO to AR }}$}

$\begin{array}{llll}\text { Yes } & \text { Yes } & \text { No } & \text { No } \\ \text { to } & \text { to } & \text { to } & \text { to } \\ \text { yes } & \underline{\text { no }} & \text { yes } & \underline{\text { no }}\end{array}$

$\begin{array}{llll}92 & 5 & 0 & 3\end{array}$

$\begin{array}{llll}8 & 3 & 5 & 85\end{array}$

$\begin{array}{llll}15 & 5 & 10 & 69\end{array}$

$3 \quad 10 \quad 5 \quad 82$

85

30

395

$\begin{array}{lll}39 & 39 & 39\end{array}$

\begin{tabular}{|c|c|c|}
\hline \multirow{2}{*}{\multicolumn{3}{|c|}{$\frac{\mathrm{BP}}{\text { Non-biotechnology firms }} \stackrel{\mathrm{IPO}}{\mathrm{AR}}$}} \\
\hline & & \\
\hline 100 & 97 & 93 \\
\hline 6 & 16 & 18 \\
\hline 13 & 22 & 32 \\
\hline 19 & 13 & 11 \\
\hline 44 & 16 & 11 \\
\hline 3 & 3 & 7 \\
\hline 9 & 9 & 7 \\
\hline 32 & 32 & 28 \\
\hline
\end{tabular}

$\underline{\mathrm{BP} \text { to } \mathrm{AR}}$

$\begin{array}{llll}\begin{array}{l}\text { Yes } \\ \text { to } \\ \text { yes }\end{array} & \begin{array}{l}\text { Yes } \\ \text { to } \\ \text { no }\end{array} & \begin{array}{l}\text { No } \\ \text { to } \\ \text { yes }\end{array} & \begin{array}{l}\text { No } \\ \text { to } \\ \text { no }\end{array} \\ 92 & 8 & 0 & 0 \\ 3 & 5 & 10 & 82 \\ 8 & 3 & 18 & 72 \\ 5 & 8 & 0 & 85 \\ 8 & 36 & 5 & 51 \\ 3 & 3 & 3 & 92 \\ 3 & 5 & 5 & 87 \\ 39 & 39 & 39 & 39\end{array}$


Table 5

\section{Assets and Technology}

Percent of companies that have patented technology, physical assets, alienable assets (either physical assets or patents), and proprietary intellectual property for 49 VC-financed companies that subsequently went public. We also report the percentages of companies for which these are or are not constant over time (e.g. The "yes to no" column under "BP to IPO" reflects the percentage of companies who report a given item as part of their assets in the business plan but not at the IPO).

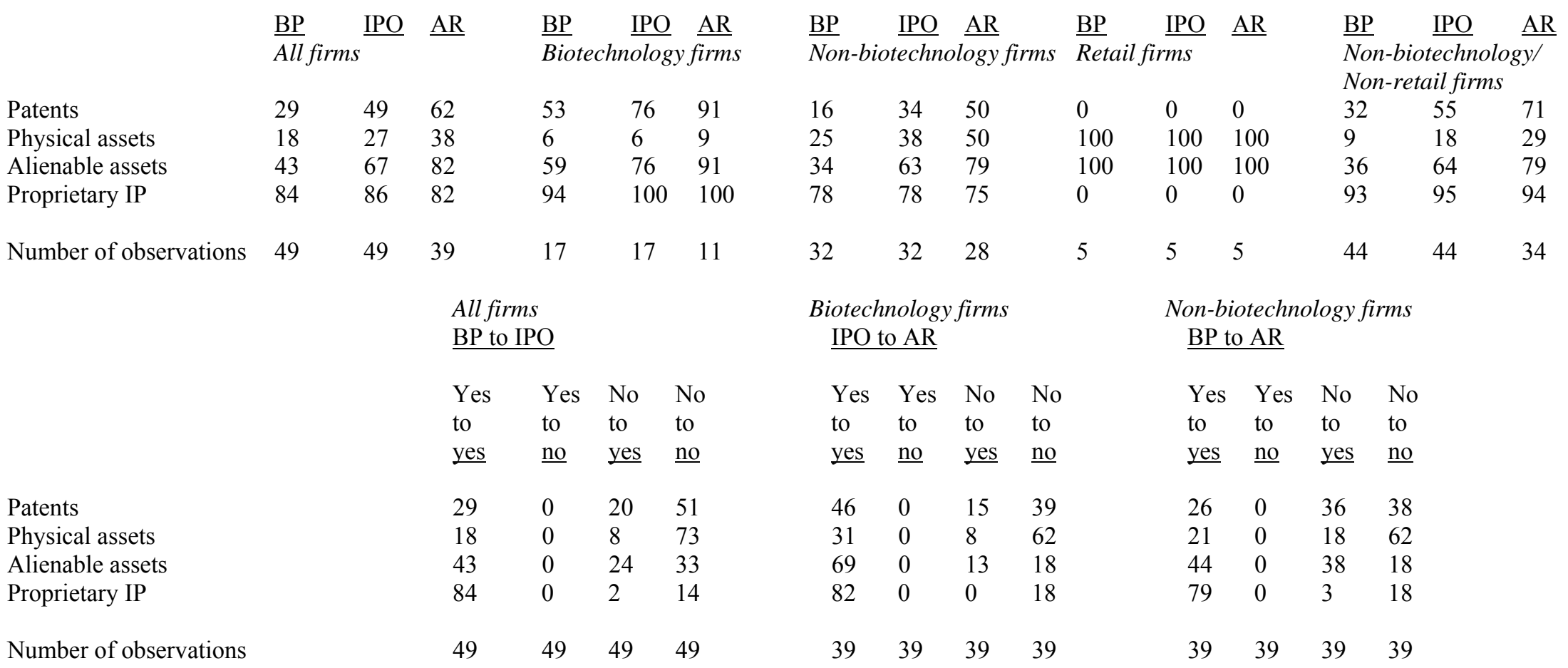


Table 6

\section{Growth Strategy}

Percent of companies that explicitly report the following as elements of their growth strategy for $49 \mathrm{VC}$-financed companies that subsequently went public: increase market penetration or establish market or technology leadership, develop new products or upgrade existing products, develop new strategic alliances or other business partnerships, expand geographically, acquire other companies. We also report the percentages of companies who do or do not change the elements of their strategies over time (e.g. The "yes to no" column under "BP to IPO" reflects the percentage of companies who report a given item as part of their growth strategy in the business plan but not at the IPO).

Market penetration/leadership

New/upgraded products

Expand geographically

New alliances/partnerships

Acquisitions

Number of observations

Market penetration/leadership New/upgraded products

Expand geographically New alliances/partnerships

Acquisitions

Number of observations

\begin{tabular}{|c|c|}
\hline $\mathrm{BP}$ & IPC \\
\hline & \\
\hline 49 & 71 \\
\hline 59 & 82 \\
\hline 20 & 43 \\
\hline 29 & 59 \\
\hline 2 & 22 \\
\hline 49 & 49 \\
\hline
\end{tabular}

BP to IPO

Yes Yes No No

to to to to

$\frac{\text { yes }}{47} \quad \frac{\text { no }}{2} \quad \frac{\text { yes }}{24} \quad \frac{\text { no }}{27}$

$\begin{array}{llll}53 & 6 & 29 & 12\end{array}$

$\begin{array}{llll}14 & 6 & 29 & 51\end{array}$

$\begin{array}{llll}24 & 4 & 35 & 37\end{array}$

$\begin{array}{llll}2 & 0 & 20 & 78\end{array}$

$\begin{array}{llll}49 & 49 & 49 & 49\end{array}$

$\begin{array}{lll}\frac{\mathrm{BP}}{\text { Biotechnology }} & \underline{\mathrm{IPO}} & \underline{\mathrm{AR}} \\ 24 & 47 & 55 \\ 94 & 100 & 91 \\ 0 & 6 & 0 \\ 47 & 71 & 64 \\ 0 & 29 & 27 \\ & & \\ 17 & 17 & 11\end{array}$

IPO to AR

\begin{tabular}{|c|c|c|}
\hline Yes & Yes & No \\
\hline to & to & to \\
\hline yes & $\underline{\text { no }}$ & yes \\
\hline 49 & 21 & 8 \\
\hline 64 & 15 & 8 \\
\hline 21 & 26 & 0 \\
\hline 51 & 8 & 0 \\
\hline 10 & 10 & 18 \\
\hline 39 & 39 & 39 \\
\hline
\end{tabular}

$\begin{array}{lcc}\frac{\mathrm{BP}}{\text { Non-biotechnology }} & \underline{\mathrm{IPO}} & \underline{\mathrm{AR}} \\ 63 & 84 & 57 \\ 41 & 72 & 64 \\ 31 & 63 & 29 \\ 19 & 53 & 46 \\ 3 & 19 & 29 \\ 32 & 32 & 28\end{array}$

\section{BP to AR}

$\begin{array}{llll}\begin{array}{l}\text { Yes } \\ \text { to }\end{array} & \begin{array}{l}\text { Yes } \\ \text { to }\end{array} & \begin{array}{l}\text { No } \\ \text { to }\end{array} & \begin{array}{l}\text { No } \\ \text { to }\end{array} \\ \underline{\text { yes }} & \underline{\text { no }} & \frac{\text { yes }}{15} & \frac{\text { no }}{28} \\ 51 & 5 & 21 & 23 \\ 13 & 13 & 8 & 67 \\ 23 & 2 & 28 & 46 \\ 3 & 0 & 26 & 72 \\ 39 & 39 & 39 & 39\end{array}$


Table 7

\section{Customers}

Percent of companies that have customers at the business plan, IPO, and annual report for 49 VC-financed companies that subsequently went public. We also report whether the customer base is primarily businesses or consumers, and whether the customer base broadens, narrows, or stays about the same over time.

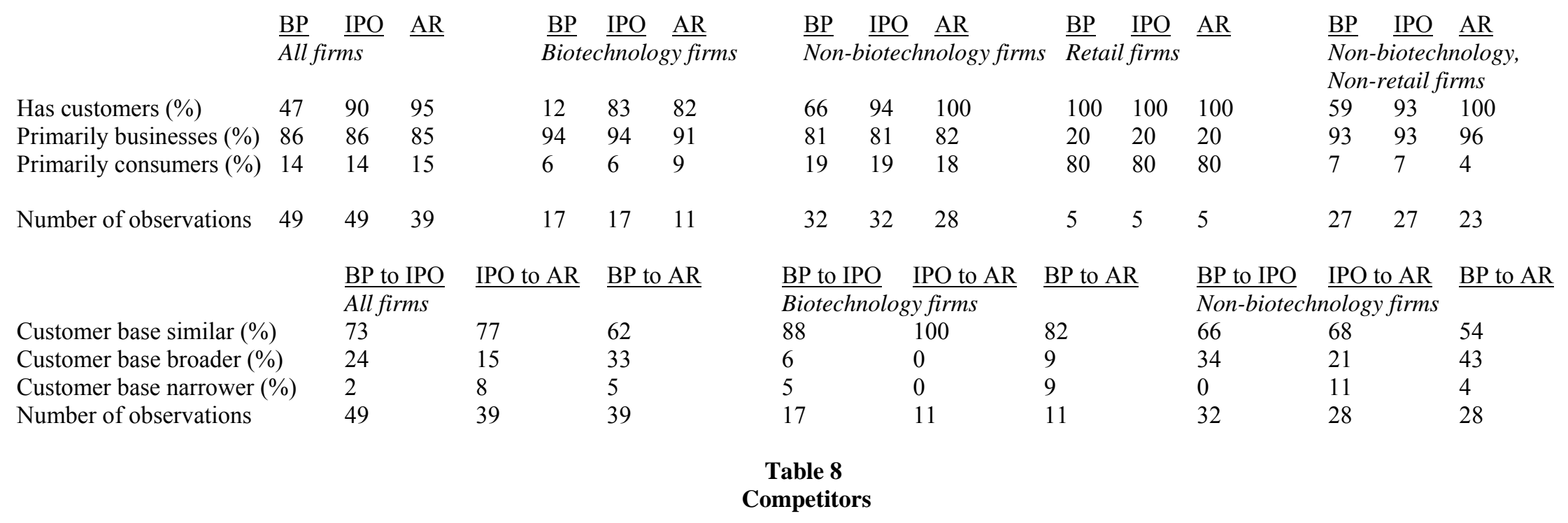

Percent of companies who have competitors at the business plan for $49 \mathrm{VC}$-financed companies that subsequently went public. We also report the percent of companies whose competitor base broadens, narrows, or stays about the same over time.

Number of observations: $49 \quad$ Lists competitors as of business plan (\%): 84

\begin{tabular}{|c|c|c|c|c|c|c|c|c|c|}
\hline & $\frac{\text { BP to IPO }}{\text { All firms }}$ & $\underline{\mathrm{IPO} \text { to } \mathrm{AR}}$ & $\underline{\mathrm{BP}}$ to $\mathrm{AR}$ & $\frac{\mathrm{BP} \text { to IPO }}{\text { Biotechnol }}$ & $\frac{\text { IPO to AR }}{\text { gy firms }}$ & $\underline{\mathrm{BP}}$ to $\mathrm{AR}$ & $\frac{\mathrm{BP} \text { to IPO }}{\text { Non-biotech }}$ & $\frac{\text { IPO to AR }}{\text { nology firms }}$ & $\underline{\mathrm{BP}}$ to $\mathrm{AR}$ \\
\hline Competitor base similar ( $\%)$ & 63 & 79 & 56 & 47 & 82 & 36 & 72 & 79 & 64 \\
\hline Competitor base broader (\%) & 35 & 21 & 41 & 53 & 18 & 64 & 25 & 21 & 32 \\
\hline Competitor base narrower $(\%)$ & 2 & 0 & 3 & 0 & 0 & 0 & 3 & 0 & 4 \\
\hline Number of observations & 49 & 39 & 39 & 17 & 11 & 11 & 32 & 28 & 28 \\
\hline
\end{tabular}


Table 9

Strategic alliances and other business partnerships

Percent of companies that explicitly mention strategic alliances or other business partnerships as elements of their business for $49 \mathrm{VC}$-financed companies that subsequently went public. For those that do report alliances, we report the median, average, and standard deviation of the number of reported alliances or partnerships; the number and percent of alliances or partnerships that remain over time; and the number of new alliances or partnerships over time.

\begin{tabular}{|c|c|c|c|c|c|c|c|c|c|}
\hline \multirow[b]{2}{*}{ Alliances mentioned (\%) } & \multicolumn{2}{|c|}{$\frac{\mathrm{BP}}{\text { All firms }}$} & $\underline{\mathrm{AR}}$ & \multicolumn{3}{|c|}{$\frac{\mathrm{BP}}{\text { Biotechnology firms }}$} & \multicolumn{3}{|c|}{$\frac{\mathrm{BP}}{\text { Non-biotechnology firms }}$} \\
\hline & 35 & 67 & 69 & 18 & 82 & 82 & 44 & 59 & 64 \\
\hline Num. Obs. & 49 & 49 & 39 & 17 & 17 & 11 & 32 & 32 & 28 \\
\hline \multicolumn{10}{|l|}{ Number reported alliances } \\
\hline & \multicolumn{3}{|c|}{ All firms } & \multicolumn{3}{|c|}{ Biotechnology firms } & \multicolumn{3}{|c|}{ Non-biotechnology firms } \\
\hline Median & 2.0 & 3.0 & 4.0 & 2.0 & 3.0 & 4.0 & 2.0 & 3.0 & 6.5 \\
\hline Average & 2.2 & 3.3 & 5.4 & 2.0 & 3.1 & 4.0 & 2.3 & 3.5 & 7.1 \\
\hline Standard deviation & 1.3 & 2.1 & 4.6 & 1.0 & 1.7 & 2.6 & 1.5 & 2.5 & 6.1 \\
\hline Num. Obs. & 11 & 26 & 18 & 3 & 13 & 10 & 8 & 13 & 8 \\
\hline & & & & $\underline{\mathrm{BP}}$ & $\underline{\text { IPO }}$ & & & & to $\mathrm{AR}$ \\
\hline \multicolumn{10}{|c|}{ Number alliances still existing } \\
\hline \multicolumn{4}{|c|}{ Median } & \multicolumn{2}{|l|}{1.0} & \multicolumn{2}{|c|}{1.0} & \multicolumn{2}{|c|}{1.0} \\
\hline \multirow{2}{*}{\multicolumn{4}{|c|}{$\begin{array}{l}\text { Average } \\
\text { Standard deviation }\end{array}$}} & \multirow{2}{*}{\multicolumn{2}{|c|}{$\begin{array}{l}1.0 \\
0.7\end{array}$}} & \multirow{2}{*}{\multicolumn{2}{|c|}{$\begin{array}{l}1.6 \\
1.4\end{array}$}} & \multicolumn{2}{|c|}{0.7} \\
\hline & & & & & & & & 0. & \\
\hline \multicolumn{4}{|l|}{ Num. Obs. } & \multicolumn{2}{|l|}{9} & \multicolumn{2}{|c|}{14} & \multicolumn{2}{|l|}{7} \\
\hline \multicolumn{10}{|c|}{ Percent alliances still existing } \\
\hline \multicolumn{4}{|c|}{ Median } & \multicolumn{2}{|l|}{67} & \multicolumn{2}{|c|}{42} & \multicolumn{2}{|c|}{20} \\
\hline \multicolumn{4}{|l|}{ Average } & \multicolumn{2}{|l|}{60} & \multicolumn{2}{|c|}{46} & \multicolumn{2}{|c|}{39} \\
\hline Standard deviation & & & & 44 & & 38 & & 46 & \\
\hline Num $=100 \%$ & & & & 4 & & 3 & & 2 & \\
\hline Num. $=0 \%$ & & & & 2 & & 3 & & 3 & \\
\hline Num. Obs. & & & & 9 & & 14 & & 7 & \\
\hline Number new alliances & & & & & & & & & \\
\hline Median & & & & 2.0 & & 3. & & 4. & \\
\hline Average & & & & 2.5 & & 4. & & 5. & \\
\hline Standard deviation & & & & 2.2 & & 3. & & 4. & \\
\hline Num. Obs. & & & & 20 & & 15 & & 13 & \\
\hline
\end{tabular}


Table 10

Management

Percent of companies whose top 5 managers include a chief executive officer (CEO), a chief technologist, scientist or similar (CTO), a chief financial officer (CFO) or similar, and a marketing or sales director or similar (CMO) for $49 \mathrm{VC}$-financed companies that subsequently went public. The table also reports whether a founder is the CEO or, if not, a director; the extent of executive turnover; and the backgrounds of the business plan management team.

Panel A:

\section{Has a $\mathrm{CEO}(\%)$}

Num. Obs.

CEO is a founder $(\%)$

Num. Obs.

A founder is a director if none

is the $\mathrm{CEO}(\%)$

Num. Obs.

A founder is a top 5 manager or a director

Num. Obs.

Has a CFO or similar (\%)

Num. Obs.

Has a CMO or similar (\%)

Num. Obs.

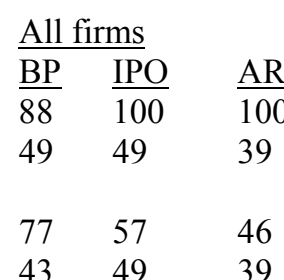

Biotechnology firms

\begin{tabular}{ll}
\hline BP & $\underline{\text { IPO }}$ \\
17 & 100 \\
75 & 17 \\
12 & 53 \\
& 17
\end{tabular}

$\underline{\mathrm{AR}}$

11

36

11

$\begin{array}{lll}92 & 71 & 48\end{array}$

$12 \quad 21$

21

$\begin{array}{lll}100 & 92 & 72\end{array}$

$\begin{array}{lll}47 \quad 49 & 39\end{array}$

$\begin{array}{lll}42 & 80 & 85\end{array}$

$48 \quad 49 \quad 39$

$\begin{array}{lll}38 & 37 & 41\end{array}$

$\begin{array}{lll}48 & 49 & 39\end{array}$

$\begin{array}{lll}77 & 77 & 47\end{array}$

$\begin{array}{lll}43 & 44 & 34\end{array}$
75

71

7

$100 \quad 94 \quad 82$

16

17

17

71

17

12

17

82

17

76

17

\begin{tabular}{lll}
\multicolumn{2}{l}{ Non-biotechnology firms } & \\
$\frac{\mathrm{BP}}{97}$ & $\frac{\mathrm{IPO}}{100}$ & $\frac{\mathrm{AR}}{100}$ \\
32 & 32 & 28 \\
77 & 59 & 50 \\
31 & 32 & 28
\end{tabular}

$\begin{array}{lll}100 & 69 & 36\end{array}$

13

14

$\begin{array}{lll}100 & 94 & 68 \\ 31 & 32 & 28 \\ 45 & 84 & 79 \\ 31 & 32 & 28 \\ & & \\ 45 & 50 & 54 \\ 31 & 32 & 28\end{array}$

Has a CTO or similar (non-retail) (\%)

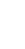

6

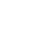

68

9

$\begin{array}{llll}11 & 31 & 32 & 28\end{array}$

Num. Obs.

\section{政}

(1)

(1)

47
34




\section{Table 10 (continued)}

$\underline{\text { Panel B: }}$

\begin{tabular}{|c|c|c|c|c|c|}
\hline & \multirow[b]{2}{*}{$\underline{\text { General mgmt }}$} & \multicolumn{4}{|c|}{$\underline{\text { All firms }}$} \\
\hline & & $\underline{\text { Technical mgmt }}$ & Technical & Marketing & Finance \\
\hline $\begin{array}{l}\text { Top } 5 \text { business plan } \\
\text { executives' background (\%) }\end{array}$ & 42 & 25 & 16 & 9 & 8 \\
\hline \multirow[t]{3}{*}{ Num. Obs. } & 47 & 47 & 47 & 47 & 47 \\
\hline & & \multicolumn{4}{|c|}{$\underline{\text { Biotechnology firms }}$} \\
\hline & General mgmt & Technical mgmt & Technical & Marketing & Finance \\
\hline $\begin{array}{l}\text { Top } 5 \text { business plan } \\
\text { executives' background (\%) }\end{array}$ & 26 & 42 & 27 & 1 & 4 \\
\hline \multirow[t]{3}{*}{ Num. Obs. } & 16 & 16 & 16 & 16 & 16 \\
\hline & & \multicolumn{4}{|c|}{$\underline{\text { Non-biotechnology firms }}$} \\
\hline & General mgmt & $\underline{\text { Technical mgmt }}$ & Technical & Marketing & Finance \\
\hline $\begin{array}{l}\text { Top } 5 \text { business plan } \\
\text { executives' background (\%) }\end{array}$ & 50 & 16 & 10 & 13 & 11 \\
\hline Num. Obs. & 31 & 31 & 31 & 31 & 31 \\
\hline
\end{tabular}

Panel C:

\section{All firms} BP to IPO

CEO remains the same $(\%)$

Num. Obs.

Next 4 top execs remaining (\%)

Num. Obs.

Former CEO still at co. (\%)

Num. Obs.

$\begin{array}{ll}84 & 5 \\ 43 & 39 \\ 55 & 36 \\ 49 & 39 \\ & \\ 29 & 19 \\ 7 & 16\end{array}$

Former next 4 execs still at co. (\%) 25

Num. Obs.
Biotechnology firms

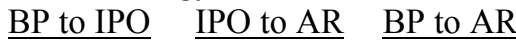

\section{PO to AR BP to AR}

59

59

39

36

39

19

16

6

38

50
36
25
39
11
18
6
42

42

$\begin{array}{lll}92 & 64 & 56 \\ 12 & 11 & 9 \\ 41 & 36 & 22 \\ 17 & 11 & 11 \\ & & \\ 0 & 25 & 25 \\ 1 & 4 & 4 \\ 29 & 18 & 2 \\ 14 & 11 & 14\end{array}$

Non-biotechnology firms

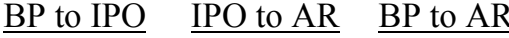

$\begin{array}{lll}81 & 57 & 48 \\ 31 & 28 & 27 \\ & & \\ 63 & 36 & 27 \\ 32 & 28 & 28 \\ & & \\ 33 & 17 & 7 \\ 6 & 12 & 14 \\ & & 7 \\ 24 & 1 & 28 \\ 27 & 27 & \end{array}$


Panel D: Departing founders/executives

\section{$\mathrm{BP}$ and IPO}

$\underline{\mathrm{BP} \text { and IPO }} \quad \underline{\mathrm{IPO} \text { and } \mathrm{AR}}$

\section{$\underline{\mathrm{IPO} \text { and } \mathrm{AR}}$}

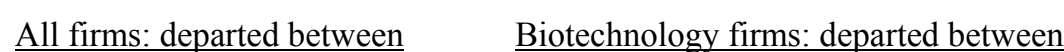

Non-biotech firms: departed between

\section{$\underline{\mathrm{BP} \text { and IPO }} \quad \underline{\mathrm{IPO} \text { and } \mathrm{AR}}$}

Identified next job (\%):

Founders

Num. Obs.

Non-founder CEOs

Num. Obs.

Non-founder other top 5

Num. Obs.

Founded new company (\%):

Founders

Num. Obs.

Non-founder CEOs

Num. Obs.

Non-founder other top 5

Num. Obs.

Top executive of startup company (\%):

Founders

Num. Obs.

Non-founder CEOs

Num. Obs.

Non-founder other top 5

Num. Obs.
50

6

0

41

32

32

17

6

0

1

11

32

):

33

6

0

1

36

32
15

60

5

42

33

10

15

0

5

4

33

27

15

40

5

36

33
50

2

33
12

50

2

4
12

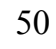

2

20.8

12
50

4

100

1

53

8

0

4

0

4

0

4

0

40

8
43

11

50

4

39

25

$20 \quad 25$


Table 11

\section{Ownership}

Panel A reports common stock ownership of company founders (taken as a group), CEOs, and non-founder CEOs at the business plan, immediately before the (pre-) IPO, immediately after the (post-)IPO, and at the annual report, as well as percentage changes in these variables. Percentage changes are from business plan to pre-IPO. Ownership at the business plan is after the financing round. Panel B summarizes the division of firm ownership pre-IPO. Panel C summarizes the shares of net value, defined as pre-IPO value minus total consideration paid by all existing investors, owned by founders and executives of the firm, assumed that none of them paid consideration to the company.

\section{Panel A - Beneficial ownership of common stock}

\begin{tabular}{lllll} 
Founder(s) (\%) & \multicolumn{2}{l}{ All firms } \\
& & Pre- & \multicolumn{1}{l}{ Post- } \\
& $\underline{\text { BP }}$ & $\underline{\underline{\text { IPO }}}$ & $\underline{\text { IPO }}$ & $\underline{\text { AR }}$ \\
Median & 28.9 & 12.4 & 8.8 & 5.3 \\
Average & 36.0 & 14.6 & 11.2 & 7.2 \\
St. dev. & 25.4 & 12.4 & 9.7 & 7.5 \\
Num. Obs. & 31 & 49 & 49 & 37
\end{tabular}

Biotechnology firms

\begin{tabular}{|c|c|c|}
\hline $\mathrm{BF}$ & $\begin{array}{l}\text { Pre- } \\
\text { IPO }\end{array}$ & $\begin{array}{l}\text { Post- } \\
\text { IPO }\end{array}$ \\
\hline 28.9 & $\overline{4.3}$ & 3.5 \\
\hline 4.4 & 11.4 & 8.6 \\
\hline 0.8 & 12.7 & 9.5 \\
\hline & 17 & 17 \\
\hline
\end{tabular}

Founder(s) percentage change

\begin{tabular}{|c|c|c|c|}
\hline & BP to IPO & IPO to AR & $\underline{\mathrm{BP}}$ to $\mathrm{AR}$ \\
\hline Median & -45 & -51 & -77 \\
\hline Average & -39 & -54 & -72 \\
\hline St. dev. & 40 & 40 & 27 \\
\hline Num Obs & 31 & 36 & 25 \\
\hline
\end{tabular}

Num. Obs. 31

CEO (\%)

\begin{tabular}{|c|c|c|c|}
\hline & $\underline{\mathrm{BP}}$ & $\begin{array}{l}\text { Pre- } \\
\text { IPO }\end{array}$ & $\begin{array}{l}\text { Post- } \\
\text { IPO }\end{array}$ \\
\hline Median & $\overline{15.9}$ & $\overline{6.7}$ & $\overline{5.4}$ \\
\hline Average & 20.1 & 9.8 & 7.5 \\
\hline St. dev. & 15.8 & 9.0 & 7.0 \\
\hline Num. Obs. & 27 & 49 & 49 \\
\hline
\end{tabular}

CEO percentage change

\begin{tabular}{|c|c|c|c|}
\hline & BP to IPO & IPO to AR & $\mathrm{BP}$ to $\mathrm{AR}$ \\
\hline Median & -38 & -50 & -78 \\
\hline Average & -31 & -40 & -69 \\
\hline St. dev. & 37 & 70 & 26 \\
\hline Num. Obs. & 27 & 38 & 23 \\
\hline
\end{tabular}

\begin{tabular}{|c|c|c|}
\hline$\underline{\mathrm{BP}}$ to IPO & IPO to AR & $\mathrm{BP}$ to $\mathrm{AR}$ \\
\hline-51 & -49 & -63.8 \\
\hline-42 & -52 & -64.1 \\
\hline 46 & 20 & 26.1 \\
\hline 9 & 10 & 7 \\
\hline
\end{tabular}

\begin{tabular}{|c|c|c|c|}
\hline BP & $\begin{array}{l}\text { Pre- } \\
\text { IPO }\end{array}$ & $\begin{array}{l}\text { Post- } \\
\text { IPO }\end{array}$ & $\underline{\mathrm{AR}}$ \\
\hline 6.8 & 4.3 & 3.1 & 3.2 \\
\hline 15.5 & 8.2 & 6.2 & 6.1 \\
\hline 14 & 9.9 & 7.1 & 8.7 \\
\hline 8 & 17 & 17 & 10 \\
\hline
\end{tabular}

\begin{tabular}{|c|c|c|}
\hline$\underline{\mathrm{BP}}$ to IPO & $\underline{\text { IPO to AR }}$ & $\underline{\mathrm{BP}}$ to $\mathrm{AR}$ \\
\hline-19 & -36 & -72.2 \\
\hline-15 & -48 & -62.9 \\
\hline 45 & 27 & 32.8 \\
\hline 8 & 10 & 7 \\
\hline
\end{tabular}

Non-biotechnology firms

\begin{tabular}{|c|c|c|}
\hline BP & $\begin{array}{l}\text { Pre- } \\
\text { IPO }\end{array}$ & $\begin{array}{l}\text { Post- } \\
\text { IPO }\end{array}$ \\
\hline$\overline{31.7}$ & $\overline{13.1}$ & $\overline{10.3}$ \\
\hline 36.7 & 16.4 & 12.6 \\
\hline 23.6 & 12.1 & 9.7 \\
\hline 22 & 32 & 32 \\
\hline
\end{tabular}

\begin{tabular}{|c|c|c|}
\hline BP to IPO & IPO to AR & $\underline{B P}$ to $\mathrm{AR}$ \\
\hline-38 & -53 & -86 \\
\hline-37 & -55 & -75 \\
\hline 38 & 45 & 27 \\
\hline 22 & 26 & 18 \\
\hline
\end{tabular}

$\begin{array}{llll}\text { BP } & \begin{array}{l}\text { Pre- } \\ \underline{\text { IPO }}\end{array} & \begin{array}{l}\text { Post- } \\ \text { IPO }\end{array} & \underline{\text { AR }} \\ 17.4 & 8.0 & 6.4 & 3.8 \\ 22.0 & 10.6 & 8.2 & 5.6 \\ 16.5 & 8.6 & 6.9 & 5.9 \\ 19 & 32 & 32 & 28\end{array}$

\begin{tabular}{|c|c|c|}
\hline$\underline{\mathrm{BP}}$ to IPO & IPO to AR & $\underline{\mathrm{BP}}$ to $\mathrm{AR}$ \\
\hline-38 & -55 & -79 \\
\hline-38 & -37 & -71 \\
\hline 32 & 80 & 23 \\
\hline 19 & 28 & 16 \\
\hline
\end{tabular}




\section{Non-founder CEO (\%)}

\begin{tabular}{|c|c|c|c|}
\hline & $\underline{\mathrm{BP}}$ & $\begin{array}{l}\text { Pre- } \\
\text { IPO }\end{array}$ & $\begin{array}{l}\text { Post- } \\
\underline{\text { IPO }}\end{array}$ \\
\hline Median & $\overline{5.5}$ & 4.2 & 3.0 \\
\hline Average & 5.1 & 5.0 & 4.0 \\
\hline St. dev. & 2.0 & 3.1 & 2.6 \\
\hline Num. Obs. & 6 & 21 & 21 \\
\hline
\end{tabular}

Non-founder CEO percentage change

\begin{tabular}{|c|c|c|c|}
\hline & BP to IPO & IPO to AR & $\underline{\mathrm{BP}}$ to $\mathrm{AR}$ \\
\hline Median & -30 & -48 & -72 \\
\hline Average & -23 & -56 & -80 \\
\hline St. dev. & 27 & 28 & 19 \\
\hline Num. Obs. & 6 & 14 & 5 \\
\hline
\end{tabular}

Panel B - Division of ownership pre-IPO (\%)

$$
\text { Non- Non-founder }
$$

founder other top

$\underline{\text { Founders }}$

CEO 5 managers

$\begin{array}{llll}\text { Median } & 12.4 & 4.2 & 2.2 \\ \text { Average } & 14.6 & 5.0 & 3.5 \\ \text { St. dev. } & 12.4 & 3.1 & 4.4 \\ \text { Num. Obs. } & 49 & 21 & 49 \\ & & & \\ & & & \\ \text { Median } & 4.3 & 3.6 & 1.6 \\ \text { Average } & 11.4 & 3.5 & 2.2 \\ \text { St. dev. } & 12.7 & 1.2 & 1.7 \\ \text { Num. Obs. } & 17 & 8 & 17 \\ & & & \\ & 13.1 & 6.6 & 2.8 \\ \text { Median } & 16.4 & 6.0 & 4.2 \\ \text { Average } & 12.1 & 3.5 & 5.2 \\ \text { St. dev. } & 32 & 13 & 32 \\ \text { Num. Obs. } & & & \end{array}$

Num. Obs. $\quad 32$

\section{Table 11 (continued)}

$\underline{\text { Biotechnology firms }}$

\begin{tabular}{|c|c|c|}
\hline$\underline{\mathrm{BP}}$ & $\begin{array}{l}\text { Pre- } \\
\text { IPO }\end{array}$ & $\begin{array}{l}\text { Post- } \\
\text { IPO }\end{array}$ \\
\hline 4.2 & 3.6 & 2.8 \\
\hline 4.2 & 3.5 & 2.7 \\
\hline 0.7 & 1.2 & 0.9 \\
\hline 2 & 8 & 8 \\
\hline
\end{tabular}

$\begin{array}{lll}\frac{\text { BP to IPO }}{-20} & \text { IPO to AR } & \text { BP to AR } \\ -20 & -33 & -86 \\ 50 & -45 & -86 \\ 2 & 37 & 20 \\ & 4 & 2\end{array}$

$\underline{\text { Non-biotechnology firms }}$

$\begin{array}{llll} & \text { Pre- } & \text { Post- } & \\ \frac{\mathrm{BP}}{6.5} & \frac{\mathrm{IPO}}{6.6} & \underline{\mathrm{IPO}} & \underline{\mathrm{AR}} \\ 5.5 & 6.0 & 4.8 & 2.0 \\ 2.4 & 3.5 & 2.9 & 1.4 \\ 4 & 13 & 13 & 14\end{array}$

$\begin{array}{llll}\underline{\text { BP to IPO }} & \text { IPO to AR } & \text { BP to AR } \\ -30 & -56 & -70 \\ -24 & -60 & -76 \\ 20 & 24 & 21 \\ 4 & 10 & 3\end{array}$

All executive officers and

$\underline{\text { VCs }} \underline{\text { Partners }}$ Others directors

$\begin{array}{llll} & & \text { All firms } & \\ 52.6 & 0.0 & 22.7 & 52.0 \\ 53.0 & 3.8 & 23.1 & 55 \\ 17.1 & 8.2 & 13.0 & 21.9 \\ 49 & 49 & 49 & 49\end{array}$

Biotechnology firms

$\begin{array}{llll}52.6 & 0.0 & 28.0 & 48.3 \\ 51.4 & 4.7 & 28.8 & 49.7 \\ 16.4 & 7.8 & 12.7 & 17.2 \\ 17 & 17 & 17 & 17\end{array}$

Non-biotechnology firms

$\begin{array}{lllll}54.1 & 0.0 & 20.5 & 56.0 & 18.9 \\ 53.9 & 3.3 & 20.1 & 57.9 & 23.0 \\ 17.6 & 8.5 & 12.3 & 23.8 & 12.7 \\ 32 & 32 & 32 & 32 & 32\end{array}$

Founder not

a mgr:

Founder $\$$ pre-IPO (\$M)

top 5 mgrs $\quad$ top 5 mgrs

16.3

20.3

13.1

49

$\begin{array}{ll}6.2 & 17.5 \\ 6.0 & 103.3 \\ 3.4 & 398.5 \\ 6 & 49\end{array}$

49

$\begin{array}{lll}8.0 & 6.1 & 11.7 \\ 15.2 & 6.1 & 29.7 \\ 12.5 & 3.6 & 39.2 \\ 17 & 2 & 17\end{array}$

6.2

6.0

3.9 
Panel C - Founder and executive shares of pre-IPO net value (\%)

\begin{tabular}{|c|c|c|c|c|c|}
\hline & $\underline{\text { Founders }}$ & $\begin{array}{l}\text { Non- } \\
\text { founder } \\
\underline{\mathrm{CEO}}\end{array}$ & $\begin{array}{l}\text { Non-founder } \\
\text { other top } \\
\underline{5 \text { managers }}\end{array}$ & $\begin{array}{l}\text { Founders }+ \\
\text { top } 5 \mathrm{mgrs}\end{array}$ & $\begin{array}{l}\text { Founder not } \\
\text { a mgr: } \\
\text { top } 5 \text { mgrs }\end{array}$ \\
\hline & & \multicolumn{4}{|c|}{ All firms } \\
\hline Median & 14.4 & 5.3 & 3.1 & 20.6 & 9.8 \\
\hline Average & 19.1 & 6.6 & 4.4 & 26.5 & 9.5 \\
\hline St. dev. & 18.1 & 3.9 & 5.0 & 19.4 & 4.5 \\
\hline Num. Obs. & 48 & 21 & 48 & 48 & 6 \\
\hline \multicolumn{6}{|c|}{$\underline{\text { Biotechnology firms }}$} \\
\hline Median & 8.7 & 4.8 & 2.9 & 15.5 & 11.7 \\
\hline Average & 14.6 & 5.3 & 3.2 & 20.4 & 11.7 \\
\hline St. dev. & 14.6 & 2.3 & 2.4 & 13.8 & 3.4 \\
\hline Num. Obs. & 16 & 8 & 16 & 16 & 2 \\
\hline \multicolumn{6}{|c|}{$\underline{\text { Non-biotechnology firms }}$} \\
\hline Median & 16.7 & 7.8 & 3.5 & 21.2 & 8.4 \\
\hline Average & 21.4 & 7.5 & 5.1 & 29.5 & 8.3 \\
\hline St. dev. & 19.5 & 4.5 & 5.9 & 21.2 & 4.9 \\
\hline Num. Obs. & 32 & 13 & 32 & 32 & 4 \\
\hline
\end{tabular}


Table 12

\section{Board of Directors}

Summary statistics on the size, composition, and turnover of the boards of directors at the business plan (BP), IPO, and annual report (AR) for $49 \mathrm{VC}$-financed companies that subsequently went public.

\begin{tabular}{|c|c|c|c|}
\hline Board Size & $\underline{\mathrm{BP}}$ & $\underline{\mathrm{IPO}}$ & $\underline{\mathrm{A}}$ \\
\hline Median & 5.0 & 7.0 & 7. \\
\hline Average & 5.0 & 6.9 & 6. \\
\hline St. dev. & 1.3 & 1.4 & 1 . \\
\hline Num. Obs. & 29 & 49 & 39 \\
\hline \multicolumn{4}{|c|}{ Number Insiders } \\
\hline Median & 2.0 & 2.0 & \\
\hline Average & 2.2 & 1.9 & \\
\hline St. dev. & 1.0 & 0.8 & . \\
\hline
\end{tabular}

Num. Obs. $\quad 28 \quad 48 \quad 39$

Number VCs

$\begin{array}{llll}\text { Median } & 2.0 & 3.0 & 1.0 \\ \text { Average } & 1.6 & 2.8 & 1.7 \\ \text { St. dev. } & 1.2 & 1.2 & 1.6 \\ & & & \\ \text { Num. Obs. } & 28 & 48 & 39\end{array}$

Number non-VC outsiders

$\begin{array}{llll}\text { Median } & 1.0 & 2.0 & 3.0 \\ \text { Average } & 1.3 & 2.2 & 3.2 \\ \text { St. dev. } & 1.3 & 1.4 & 1.1\end{array}$

Num. Obs. $\quad 28 \quad 48 \quad 39$

Percent directors remaining

$\frac{\mathrm{BP} \text { to IPO }}{71} \quad \frac{\text { IPO to AR }}{57} \quad \frac{\mathrm{BP} \text { to } \mathrm{AR}}{40}$

Num. Obs.

29

39

21 
Table 13

Determinants of Founder remaining CEO at the IPO or first Annual Report

Probit regressions of the likelihood of the founder remaining CEO of the company either at IPO or at the first annual report after going public. Independent variables are: 'Alienable assets at BP' is a dummy variable taking the value of one if the firm has either significant physical assets or patents at the time of the business plan (BP). 'Physical assets at BP' is a dummy variable taking the value of one if the firm has significant physical assets at the time of the BP. 'Patents at BP' is a dummy variable taking the value of one if the firm has patents at the time of the BP. 'Nonpat. IP at BP' is a dummy variable taking the value of one if the firm has no patents but has proprietary intellectual property at the time of BP. 'Age (months) at BP' is the age of the firm at the time of the BP in months. 'Fdr ownership at BP' is the founder's ownership stake in percent at the time of the BP. Reported coefficients are marginal effects of independent variables. . Heteroskedasticity-robust standard standard errors in parentheses. $* / * * * * *$ indicate that the coefficients are statistically significantly different from zero at the $10 \% / 5 \% / 1 \%$ level.

Panel A: Founder remains CEO at the IPO.

\begin{tabular}{|c|c|c|c|c|c|c|c|c|}
\hline Alionoble geceto & Coeff. & (STDE) & Coeff. & (STDE) & Coeff. & (STDE) & Coeff. & (STDE) \\
\hline $\begin{array}{l}\text { Alienable assets at BP } \\
\text { Physical assets at BP }\end{array}$ & & $(0.150)$ & -0.443 & $(0.198)^{* *}$ & -0.700 & $(0.164) * * *$ & -0.971 & $(0.048) * * *$ \\
\hline Patents at BP & & & -0.069 & $(0.169)$ & -0.529 & $(0.235)^{* *}$ & -0.814 & $(0.194)^{* * *}$ \\
\hline Non-pat. IP at BP & & & & & -0.504 & $(0.194)^{* * *}$ & -0.698 & $(0.167)^{* * *}$ \\
\hline Age (months) at BP & 0.002 & $(0.002)$ & 0.005 & $(0.003)^{*}$ & 0.007 & $(0.003)^{* *}$ & 0.008 & $(0.003)^{* *}$ \\
\hline Fdr ownership at BP & & & & & & & 0.014 & $(0.005)^{* *}$ \\
\hline Constant & 0.118 & $(0.270)$ & 0.009 & $(0.273)$ & 1.165 & $(0.567)^{* *}$ & 0.711 & $(0.839)$ \\
\hline Number of obs. & 49 & & 49 & & 49 & & 30 & \\
\hline Pseudo R-squared & 0.03 & & 0.07 & & 0.12 & & 0.38 & \\
\hline
\end{tabular}

Panel B: Founder remains CEO at the first Annual Report.

Tangible assets at BP

Physical assets at BP

Patents at BP

Non-pat. IP at BP

Age (months) at BP

Fdr ownership at BP

Constant

Number of obs.

Pseudo R-squared
Coeff. (STDE)

$-0.518(0.195)^{* * *}$

$\begin{array}{cl}0.014 & (0.004)^{* *} \\ -0.543 & (0.326)^{*}\end{array}$

39

0.27

\begin{abstract}
Coeff. (STDE)
\end{abstract}
$-0.50$

$-0.359$

$(0.252)^{* *}$

$(0.195)^{*}$

0.01

$-0.665$

$(0.005)^{*}$

$(0.348)^{*}$

39

0.25
Coeff. (STDE)

$-0.642 \quad(0.232)^{* * * *}$

$-0.599 \quad(0.235)^{* *}$

$\begin{array}{ll}-0.355 & (0.247)\end{array}$

$0.014(0.006)^{* *}$

$-0.012 \quad(0.605)$

39

0.28
Coeff. (STDE)

$-0.835 \quad(0.165)^{* * *}$

$\begin{array}{ll}-0.599 & (0.262)^{* *}\end{array}$

$-0.568 \quad(0.245)^{* *}$

$0.014(0.005)^{* * *}$

$0.010 \quad(0.005)^{* *}$

\begin{tabular}{ll}
$-0.445 \quad(0.843)$ \\
\hline
\end{tabular} 
Table 14

Determinants of Founder ownership pre- IPO

OLS regressions of the determinants of founder pre-IPO ownership percentage. Independent variables are 'Tangible assets at BP' is a dummy variable taking the value of one if the firm has either significant physical assets or patents at the time of the business plan (BP). 'Physical assets at BP' is a dummy variable taking the value of one if the firm has significant physical assets at the time of the BP. 'Patents at BP' is a dummy variable taking the value of one if the firm has patents at the time of the BP. 'Non-pat. IP at BP' is a dummy variable taking the value of one if the firm has no patents but has proprietary intellectual property at the time of BP. 'Age (months) at BP' is the age of the firm at the time of the BP in months. 'Fdr ownership at BP' is the founder's ownership stake in percent at the time of the BP. Probit coefficients are reported, with heteroskedasticity-robust standard errors in parentheses. $* / * * / * * *$ indicate that the coefficients are statistically significantly different from zero at the $10 \% / 5 \% / 1 \%$ level.

\begin{tabular}{|l|r|l|r|l|r|l|}
\hline & Coeff. & (STDE) & Coeff. & (STDE) & \multicolumn{1}{c|}{ Coeff. } & (STDE) \\
\hline $\begin{array}{l}\text { Tangible assets at } \\
\text { BP }\end{array}$ & -0.210 & $(3.650)$ & & & & \\
\hline $\begin{array}{l}\text { Physical assets at } \\
\text { BP }\end{array}$ & & & 5.771 & $(5.541)$ & 3.288 & $(6.555)$ \\
\hline Patents at BP & & & -5.561 & $(3.591)$ & -8.997 & $(5.036)^{*}$ \\
\hline Non-pat. IP at BP & & & & & -4.218 & $(5.301)$ \\
\hline Age (months) at BP & 0.049 & $(0.039)$ & 0.031 & $(0.033)$ & 0.040 & $(0.038)$ \\
\hline Constant & 12.738 & $(2.479)^{* * *}$ & 13.913 & $(2.384)^{* * *}$ & 17.317 & $(4.341)^{* * *}$ \\
\hline & & & & & & \\
\hline Number of obs. & 49 & & 49 & & 49 & \\
\hline R-squared & 0.04 & & 0.12 & & 0.13 & \\
\hline
\end{tabular}

